Article

\title{
Basidiomycetes Associated with Alnus glutinosa Habitats in Andros Island (Cyclades, Greece)
}

\author{
Elias Polemis, Vassiliki Fryssouli, Vassileios Daskalopoulos and Georgios I. Zervakis *
}

Laboratory of General and Agricultural Microbiology, Agricultural University of Athens, 11855 Athens, Greece; teonanac_rec1@hotmail.com (E.P.); vfrisouli@gmail.com (V.F.); vassilismks@gmail.com (V.D.)

* Correspondence: zervakis@aua.gr; Tel.: +30-210-5294341

Received: 15 May 2020; Accepted: 7 June 2020; Published: 9 June 2020

check for updates

\begin{abstract}
Alluvial forests dominated by black alder (Alnus glutinosa) are widespread in Europe along river banks and watercourses forming a habitat of renowned ecological/conservation importance. Despite the considerable interest this habitat has attracted in terms of the associated fungal diversity, very few pertinent data are available from the eastern Mediterranean. Andros island (Aegean Sea, Greece) hosts the southernmost population of A. glutinosa in the Balkan Peninsula; such stands have been systematically inventoried for several years in respect to macrofungi. In total, 187 specimens were collected and studied by examining morphoanatomic features and by evaluating (when necessary) the outcome of sequencing the internal transcribed spacer (ITS) region of nuclear ribosomal DNA (nrDNA) to elucidate their identity and obtain an insight into phylogenetic relationships. As a result, 106 species were recorded, 92 are saprotrophic and 14 form ectomycorrhizae (ECM) with alders. Twenty-one species are first national records, while 68 other species are reported for the first time from this habitat in Greece. Several findings of particular interest due to their rarity, ecological preferences and/or taxonomic status are presented in detail and discussed, e.g., six Alnicola taxa, Cortinarius americanus, Lactarius obscuratus, Paxillus olivellus and Russula pumila (among the ECMs), and the saprotrophs Entoloma uranochroum, Gymnopilus arenophilus, Hyphoderma nemorale, Lepiota ochraceofulva, Phanerochaete livescens and Psathyrella hellebosensis.
\end{abstract}

Keywords: macrofungi; Basidiomycota; mushroom diversity; ectomycorrhiza; saprotroph; alder; Aegean Sea; Mediterranean; Alnicola

\section{Introduction}

Alluvial forests with Alnus glutinosa Gaertn. and Fraxinus excelsior L. (priority habitat 91E0*; Annex I, Directive 92/43/EEC) are distributed throughout Europe, but they are generally rare and threatened since only remnants exist, mainly in central and northern Europe [1]. Alder stands are considerably less frequent in the Mediterranean region, where the repercussions of changes in the hydrological cycle caused by global warming and climate destabilization are much more evident [2]. The southernmost limit of the priority habitat 91E0* in the Balkan Peninsula is located in Andros island (Figure 1), i.e., the northernmost in the Cyclades and situated at a transition zone between continental Greece and other islands of the Aegean Archipelago. From the geomorphological point of view, it is characterized by a remarkably intense relief and by many rivulets and streams of constant flow, which are unique among most of Central and South Aegean islands. A. glutinosa trees demonstrate a patchy distribution in Andros, predominantly occurring along the main streams within the Site of Community Importance (SCI) GR4220001 and in altitudes ranging from sea level to as high as $850 \mathrm{~m}$ above sea level (a.s.l.), very close to the highest peaks of the island. In many cases black alders are mixed with Platanus orientalis L., Fraxinus ornus L. and/or Nerium oleander L. (in lower altitudes), while they also form pure stands, as it is the case at the estuaries of the Vori stream in NE Andros. 


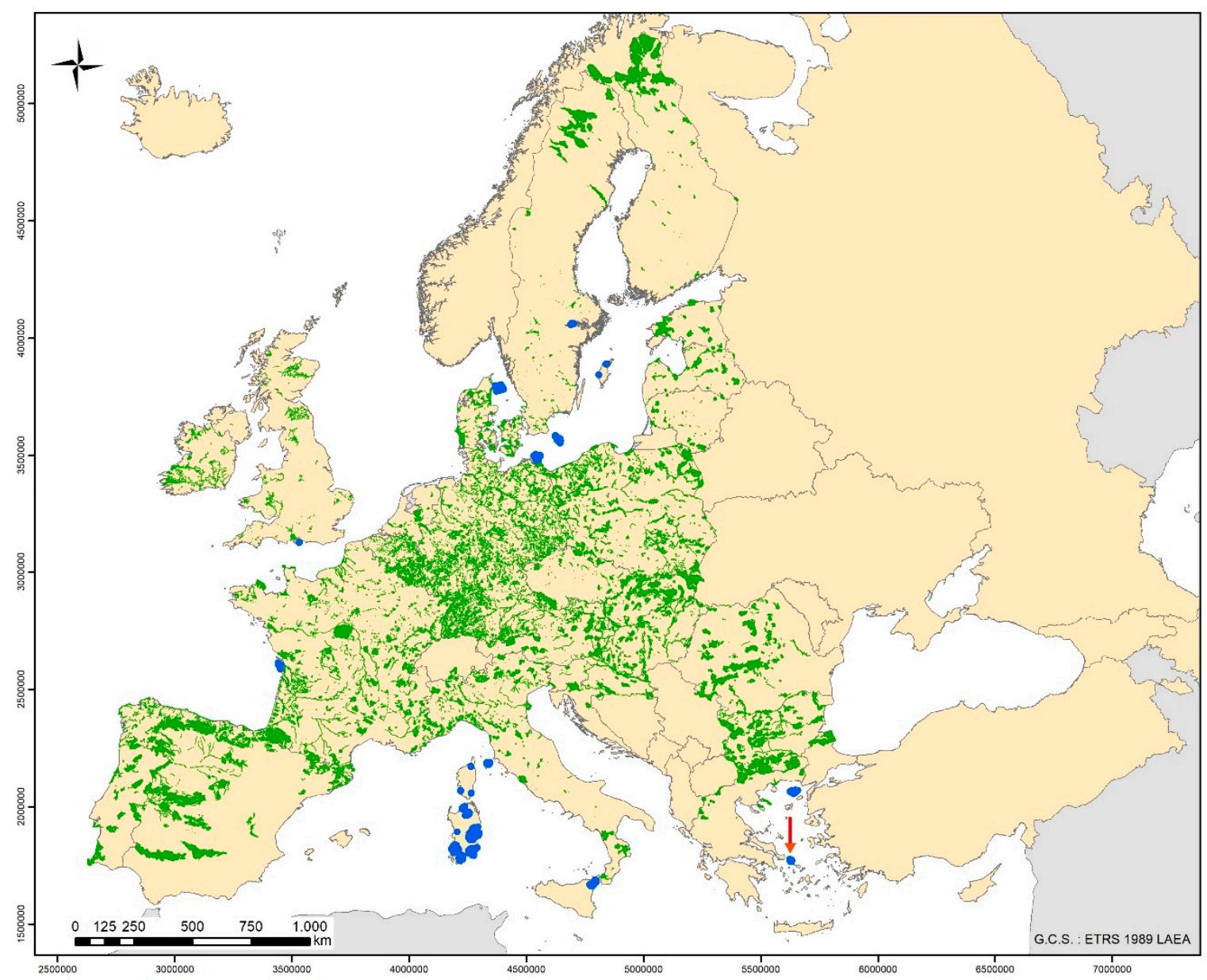

Figure 1. Map presenting Natura 2000 sites, which include the priority habitat 91E0* in continental Europe (in green) and in islands (in blue); Andros island is indicated by the red arrow. Data from https://www.eea.europa.eu/data-and-maps/data/natura-6.

Alder trees are known to form symbiotic relationships with nitrogen-fixing actinomycetes of the genus Frankia Brunchorst [3,4], with arbuscular mycorrhizal fungi (AM) of Glomeromycota [5,6] and with various ectomycorrhizal (ECM) fungi of Ascomycota and Basidiomycota [7-9]. European alder stands have been relatively well-studied in terms of both macro- and microfungal communities, and approx. 1000 species of saprotrophic and ECM macrofungi were reported [10-15]. In addition, mycocoenological studies from Europe and North America suggested that ECM fungi of Alnus spp. exhibit a remarkably high degree of host specificity compared to other tree species $[8,16]$, while the analysis of both sporophores and ectomycorrhizae evidenced that alders have a low number $(<50)$ of ECM symbionts worldwide [17-19].

Limited knowledge is available on the diversity of fungi associated with alders in Greece, and only preliminary data are reported in the few pertinent publications [20,21]. On the other hand, Andros is the only island of the Aegean Archipelago where a systematic inventory of macrofungi is in progress for more than 20 years. Biotopes characterized by river banks, springs and alluvial forests, where A. glutinosa is often the dominant tree species, were forayed in the past and 37 mushroom species were reported from this particular habitat in Andros, including ECM symbionts as well as xylotrophic, litter and/or humus saprotrophs [22-24]. Among the latter, Entoloma alnicola Noordel. \& Polemis was described asnew species for science and it is still known from the type locality only [25].

Since 2017, mycodiversity studies in alder stands of Andros were intensified in the frame of a LIFE Nature project (LIFE16-NAT_GR_000606), which -among others- aims at the conservation and restoration of the priority habitat $91 \mathrm{E} 0^{*}$ in the island. Hence, during the last few years, new 
sites with alder stands were repeatedly forayed (in addition to those previously investigated), and a large number of new collections were made. These, together with previously sampled-but still unidentified-specimens, were subjected to detailed morphoanatomical examination in conjunction with sequencing and phylogenetic analyses (where judged necessary) in order to assess their identity. Moreover, in several occasions, past relevant reports on recorded taxa were revised/re-evaluated according to the latest respective taxonomic and phylogenetic concepts. Hence, this work presents an updated compilation of available data on the diversity of macrofungi in a habitat of significant interest occurring at the limits of its distribution in Europe.

\section{Materials and Methods}

\subsection{Sampling of Biological Material}

Data presented in this inventory are based on specimens collected from 10 sampling sites covering almost the entire area of $A$. glutinosa distribution in Andros island, which appears mainly within (or marginally out) the SCI GR4220001, extending from sea-level to an altitude of ca. $850 \mathrm{~m}$ a.s.1. (Figure 2; Table S1).The biological material examined for the purpose of this work was sampled in 38 forays performed during the last 25 years from late October to April; more than half of those (\#23) were conducted in the period from 2017 to 2020. In total, 187 specimens found exclusively under alder trees or directly on their wood, woody residues or leaf-litter were collected, and voucher specimens are deposited in the Fungarium of the Laboratory of General and Agricultural University of Athens (ACAM).

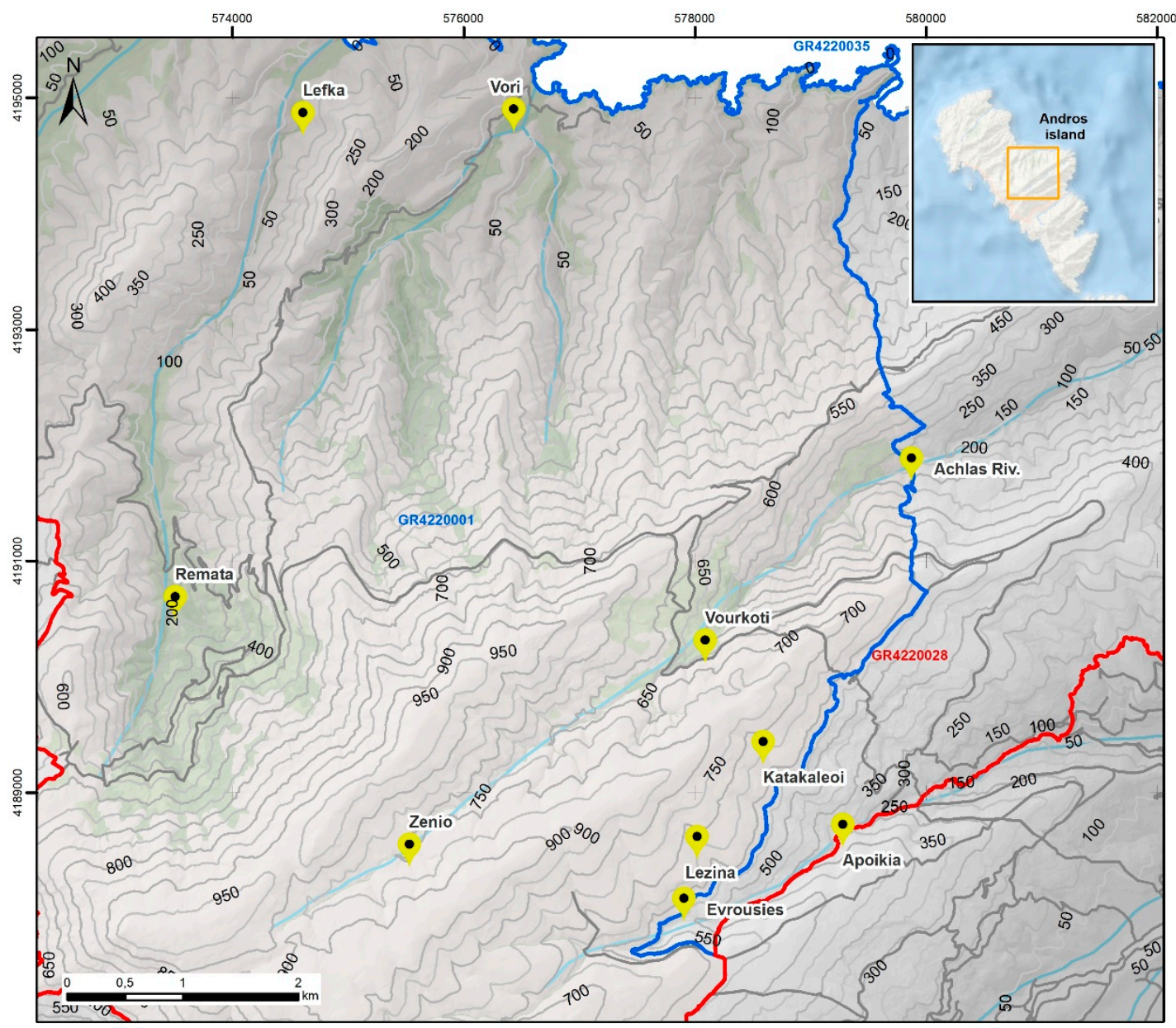

Figure 2. Sampling sites (in yellow marking) in the Alnus glutinosa habitat and relative position/size of the area under investigation within Andros island (map in upper right corner). 


\subsection{Morpho-Anatomical Features in Basidiomes}

The morphological study included in situ recording of macroscopic features of taxonomic interest, while ex-situ examination involved observations of morphoanatomical characters in dried specimens. Sections were mounted and observed in $\mathrm{KOH} 3-5 \%(w / v)$, in Melzer's reagent, in cotton-blue, in cresyl-blue and in sulfovaniline solution. Observations were performed with the use of a Zeiss AxioImager A2 microscope under bright field and differential interference contrast (DIC); microphotographs were taken with the aid of a mounted digital camera (Axiocam). For all examined specimens a minimum of 30 mature basidiospores were measured and the resulting measurements as well as additional observations of other essential microscopical features (hymenial cystidia, pileipellis etc.) were used for determination of the species examined in accordance to pertinent identification keys and monographs (e.g., [26-36]).

\subsection{DNA Extraction, Amplification and Sequencing}

When deemed necessary, DNA sequencing and phylogenetic analyses were performed. Total genomic DNA was obtained from dried basidiomes and DNA extraction was performed through the use of the Nucleospin Plant II DNA kit (Macherey and Nagel, Düren, Germany) by following the manufacturer's protocol. The internal transcribed spacer (ITS; ITS1, 5.8S, ITS2) region within the nuclear ribosomal RNA gene cluster was examined by using the primers ITS1/ITS4 [37]. Polymerase chain reactions (PCR) were performed in $50 \mu \mathrm{L}$ containing $50 \mathrm{ng}$ DNA template, $0.25 \mu \mathrm{M}$ of each primer, $0.2 \mathrm{mM}$ of each dNTP, $1 \times$ HiFi Buffer (Takara BIO INC., Shiga, Japan) and $1 \mathrm{U}$ HiFi Taq DNA polymerase (Takara BIO INC., Shiga, Japan). PCR reactions were performed as follows: $94^{\circ} \mathrm{C}$ for $5 \mathrm{~min}$, followed by 35 cycles of $94^{\circ} \mathrm{C}$ for $30 \mathrm{~s}, 50{ }^{\circ} \mathrm{C}$ for $30 \mathrm{~s}$ and $72{ }^{\circ} \mathrm{C}$ for $1 \mathrm{~min}$, and a final extension at $72{ }^{\circ} \mathrm{C}$ for $10 \mathrm{~min}$. PCR products were run in $1 \%$ agarose gels and purified using Invitrogen PureLink kit (Thermo Fisher Scientific, Seoul, S. Korea), and were submitted for sequencing to CeMIA SA (Larissa, Greece). The same PCR primers were used for sequencing. Chromatograms were checked with the aid of BioEdit v. 7.2.5 software [38]. Then sequences were examined against GenBank built-in search tools for obtaining information which could confer at identifying the material under study. A total of 61 validated sequences generated in this work were deposited in GenBank and the accession numbers MT458502 to MT458562 were obtained.

\subsection{Phylogenetic Analysis of Sequence Data}

A total of 42, 29 and 22 ITS sequences corresponding to selected species of the genera Alnicola Kühner (and Naucoria (Fr.) P. Kumm.), Lactarius Pers. and Paxillus Fr. (including 12, 5 and 4 sequences generated in this work), respectively, were subjected to phylogenetic analysis. In addition, species of the same or other genera were used as outgroups in each case. Multiple sequence alignment of each ITS rDNA dataset was conducted using the Q-INS-I algorithm as implemented in the online version of MAFFT v. 7 [39]. Alignments were reviewed, manually adjusted at misaligned sites and trimmed at the same position through MEGA X [40] before being used for further analysis.

Phylogenetic relationships of taxa for each alignment were inferred by using maximum likelihood (ML) and Bayesian inference (BI) through the CIPRES web portal (www.phylo.org; Miller et al. 2010). ML analyses were conducted by RAxML BlackBox online server (http://phylobench.vital-it.ch/raxml$\mathrm{bb} /$ ) [41] using default parameters and calculating bootstrap statistics according to the program recommendations for the best-scoring ML tree. BI analyses were performed by MrBayes v. 3.2.1 [42]. The best-fit substitution model for each dataset was selected according to the corrected Akaike information criterion (cAIC), as implemented in jModeltest v.2 [43]. The TPM2uf $+\mathrm{G}, \mathrm{TPM} 1 \mathrm{uf}+\mathrm{G}$ and SYM $+\mathrm{G}$ models were selected for the Alnicola, Lactarius and Paxillus datasets, respectively. To estimate posterior probabilities, Markov chain Monte Carlo (MCMC) simulation was implemented in two parallel independent runs of four chains, one cold and three heated, with trees sampled every 1000 generations until the standard deviation of split frequencies is below 0.05 ; the first $25 \%$ of trees were omitted as 
burn-in. A 50\% majority rule consensus tree was built and visualized with iTOL [44]. Clades with ML bootstrap support (MLB) $\geq 65 \%$ and Bayesian posterior probability (BPP) $\geq 95 \%$ were considered as significantly supported.

\section{Results and Discussion}

The study of 187 specimens of macrofungi associated with the A. glutinosa priority habitat in Andros led to the identification of 106 species (74 genera) of basidiomycetes. Among them, $14(13 \%)$ are ECM species (Table 1) strictly associated with alders $[18,19]$. The other $92(87 \%)$ are saprotrophic; $70(66 \%)$ saproxylic and $22(21 \%)$ saprotrophic on soil, humus or leaf-litter (Table 2). Interestingly, 10 ECM and 11 saprotrophic species are first national records, while other 68 are reported for the first time from this habitat in Greece. Identification of specimens to species was performed by examining their morphoanatomic features and by evaluating (when necessary) the outcome of ITS sequencing and phylogenetic analysis; in the latter case, the respective GenBank accession numbers are provided (Tables 1 and 2). Selected findings of particular interest are presented (and discussed) by providing brief descriptions and comments on characters of potentially diagnostic value.

Table 1. Ectomycorrhizal (ECM) fungi identified during the study: species name, specimen code/collection date, locality and GenBank accession numbers for ITS sequences generated. First national records for Greece are indicated by an asterisk $\left(^{*}\right)$ before the species name.

\begin{tabular}{|c|c|c|c|c|}
\hline $\mathbf{a} / \mathbf{a}$ & Species Name & $\begin{array}{l}\text { Specimen Code/ } \\
\text { Collection Date }\end{array}$ & Locality & $\begin{array}{c}\text { GenBank } \\
\text { Accession No. }\end{array}$ \\
\hline \multirow{6}{*}{1} & \multirow{6}{*}{$\begin{array}{l}\text { *Alnicola escharoides } \\
\text { (Fr.) Romagn. }\end{array}$} & EP.17-A1344/11-Nov-2017 & Zenio & \\
\hline & & EP.17-A1420/24-Nov-2017 & Vori & \\
\hline & & EP.18-A1548/22-Feb-2018 & Vori & MT458538 \\
\hline & & EP.18-A1561/1-Nov-2018 & Zenio & MT458539 \\
\hline & & EP.18-A1571/2-Nov-2018 & Vourkoti & MT458540 \\
\hline & & EP.19-A1636/16 Nov 2019 & Katakalaioi & \\
\hline 2 & $\begin{array}{l}\text { *Alnicola inculta } \\
\text { (Peck) Singer }\end{array}$ & EP.17-A1346/11 Nov 2017 & Zenio & MT458541 \\
\hline 3 & $\begin{array}{c}\text { *Alnicola luteolofibrillosa } \\
\text { Kühner }\end{array}$ & EP.17-A1430/24-Nov-2017 & Vori & MT458542 \\
\hline \multirow{2}{*}{4} & \multirow{2}{*}{$\begin{array}{c}\text { *Alnicola subconspersa } \\
\text { (Kühner ex P.D. Orton) Bon }\end{array}$} & EP.17-A1421/24-Nov-2017 & Vori & MT458543 \\
\hline & & EP.19-A1637/16-Nov-2019 & Katakalaioi & MT458544 \\
\hline \multirow{2}{*}{5} & \multirow{2}{*}{$\begin{array}{l}\text { Alnicola striatula } \\
\text { (P.D. Orton) Romagn. }\end{array}$} & EP.04-A679/15-Nov-2004 & Evrousies & \\
\hline & & EP.19-A1614/14-Nov-2019 & Evrousies & MT458545 \\
\hline \multirow{7}{*}{6} & \multirow{7}{*}{$\begin{array}{l}{ }^{*} \text { Alnicola umbrina } \\
\text { (R. Maire) Kühner }\end{array}$} & EP.04-A678/15-Nov-2004 & Evrousies & \\
\hline & & EP.17-A1377/2-Nov-2017 & Lezina & MT458546 \\
\hline & & EP.18-A1572/2-Nov-2018 & Vourkoti & MT458547 \\
\hline & & EP.19-A1607/12 Nov 2019 & Zenio & MT458548 \\
\hline & & EP.19-A1638/16-Nov-2019 & Katakalaioi & \\
\hline & & EP.19-A1646/17-Nov-2019 & Achlas riv. & \\
\hline & & EP.19-A1666/2-Dec-2019 & Remata & MT458549 \\
\hline 7 & $\begin{array}{c}{ }^{*} \text { Cortinarius americanus } \\
\text { A.H. Sm. }\end{array}$ & EP.19-A1622/15-Nov-2019 & Vourkoti & \\
\hline \multirow[b]{2}{*}{8} & \multirow{2}{*}{$\begin{array}{l}\text { Gyrodon lividus } \\
\text { (Bull.) Sacc. }\end{array}$} & EP.14-A1263/1-Nov-2014 & Vori & \\
\hline & & EP.17-A1428/24-Nov-2017 & Vori & \\
\hline 9 & $\begin{array}{c}\text { *Inocybe calospora } \\
\text { Quél. }\end{array}$ & EP.18-A1570/2-Nov-2018 & Vourkoti & MT458550 \\
\hline \multirow{5}{*}{10} & \multirow{5}{*}{$\begin{array}{l}\text { *Lactarius obscuratus } \\
\text { (Lasch) Fr. }\end{array}$} & EP.17-A1347/11-Oct-2017 & Zenio & MT458551 \\
\hline & & EP.17-A1566/1-Nov-2018 & Zenio & MT458552 \\
\hline & & EP.17-A1576/2-Nov-2018 & Vourkoti & MT458553 \\
\hline & & EP.19-A1645/17-Nov-2019 & Achlas riv. & MT458554 \\
\hline & & EP.19-A1664/30-Nov-2019 & Remata & MT458555 \\
\hline
\end{tabular}


Table 1. Cont.

\begin{tabular}{|c|c|c|c|c|}
\hline$a / a$ & Species Name & $\begin{array}{l}\text { Specimen Code/ } \\
\text { Collection Date }\end{array}$ & Locality & $\begin{array}{c}\text { GenBank } \\
\text { Accession No. }\end{array}$ \\
\hline 11 & $\begin{array}{l}\text { *Paxillus olivellus } \\
\text { P.-A. Moreau, J.-P. Chaumeton, } \\
\text { Gryta \& Jarge }\end{array}$ & $\begin{array}{c}\text { EP.95-A028/13-Nov-1995 } \\
\text { EP.02-A353/22-Sep-2002 } \\
\text { EP.04-A670/23-Oct-2004 } \\
\text { EP.04-A673/24-Oct-2004 } \\
\text { EP.14-A1266/1-Nov-2014 } \\
\text { EP.17-A1348/11-Nov-2017 } \\
\text { EP.17-A1396/23-Nov-2017 } \\
\text { EP.17-A1426/24-Nov-2017 } \\
\text { EP.18-A1552/22-Feb-2018 } \\
\text { EP.18-A1583/2-Nov-2018 } \\
\text { EP.19-A1628/16-Nov-2019 }\end{array}$ & $\begin{array}{l}\text { Achlas riv. } \\
\text { Evrousies } \\
\text { Remata } \\
\text { Achlas riv. } \\
\text { Vori } \\
\text { Zenio } \\
\text { Evrousies } \\
\text { Vori } \\
\text { Vori } \\
\text { Vourkoti } \\
\text { Katakalaioi }\end{array}$ & $\begin{array}{l}\text { MT458556 } \\
\text { MT458557 } \\
\text { MT458558 } \\
\text { MT458559 }\end{array}$ \\
\hline 12 & $\begin{array}{c}{ }^{*} \text { Russula pumila } \\
\text { Rouzeau \& F. Massart }\end{array}$ & EP.18-A1575/2-Nov-2018 & Vourkoti & MT458560 \\
\hline 13 & $\begin{array}{l}\text { Tomentella stuposa } \\
\text { (Link) Stalpers }\end{array}$ & EP.02-A327/29-Apr-2002 & Vori & MT458561 \\
\hline 14 & $\begin{array}{l}\text { Tomentella sublilacina } \\
\text { (Ellis \& Holw.) Wakef. }\end{array}$ & $\begin{array}{c}\text { EP.02-A452/11-Oct-2002 } \\
\text { EP.17-A1437/24-Nov-2017 }\end{array}$ & $\begin{array}{l}\text { Achlas riv. } \\
\text { Vori }\end{array}$ & MT458562 \\
\hline
\end{tabular}

Table 2. Saprotrophic basidiomycetes identified during the study: species name, specimen code/collection date, locality, type of substrate and GenBank accession numbers for ITS sequences generated. First national records for Greece are indicated by an asterisk ${ }^{*}$ ) before the species name.

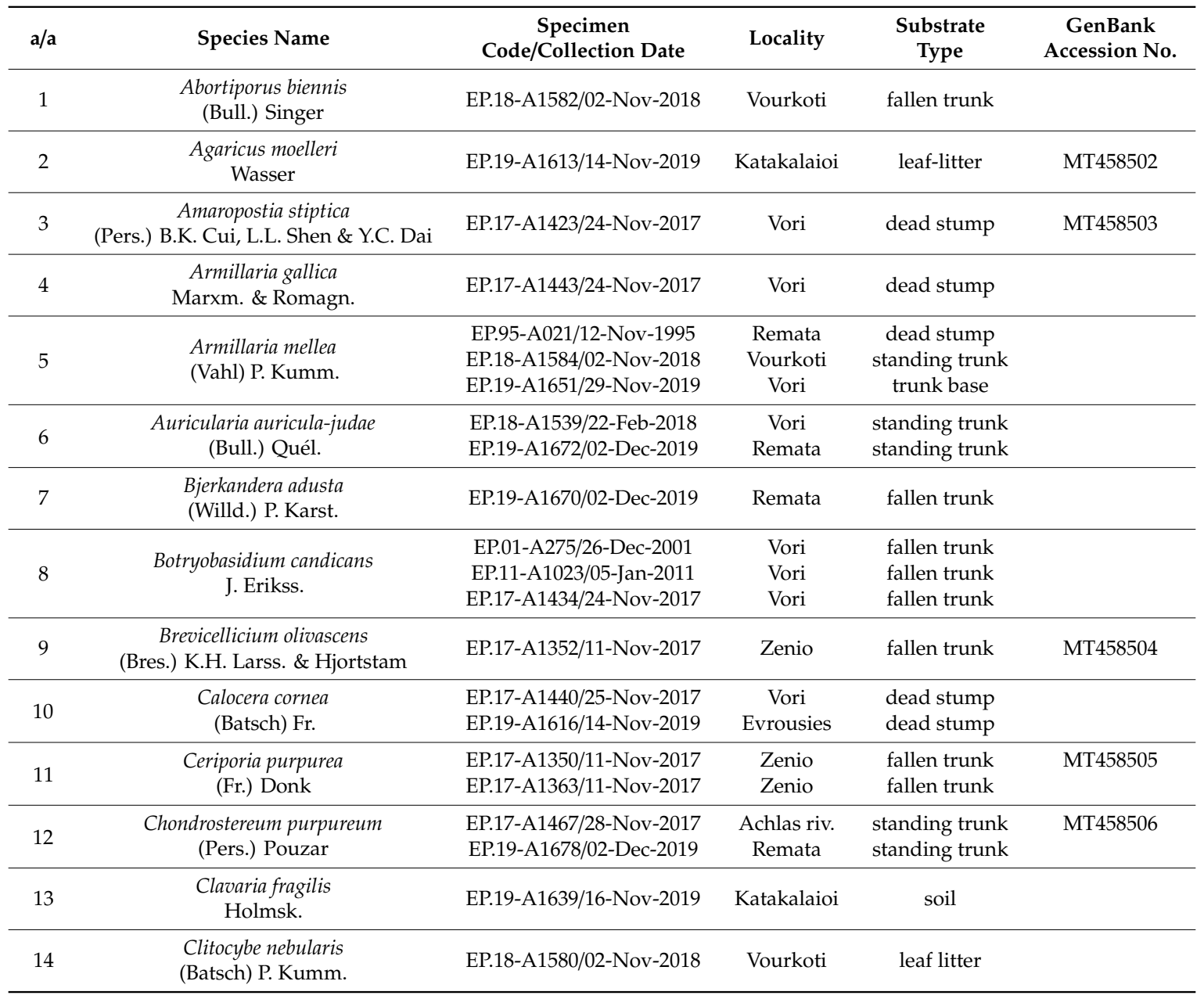


Table 2. Cont

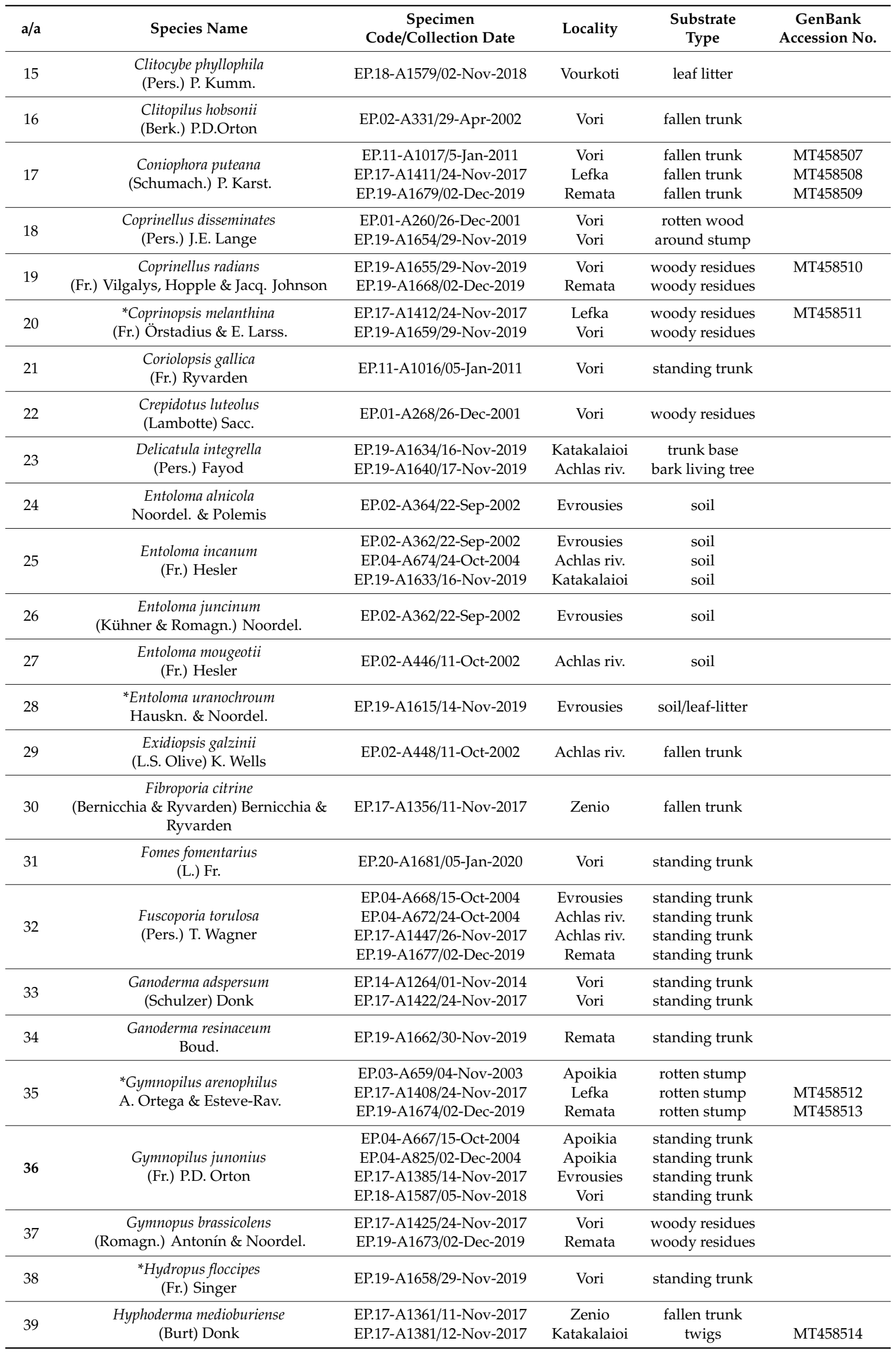


Table 2. Cont

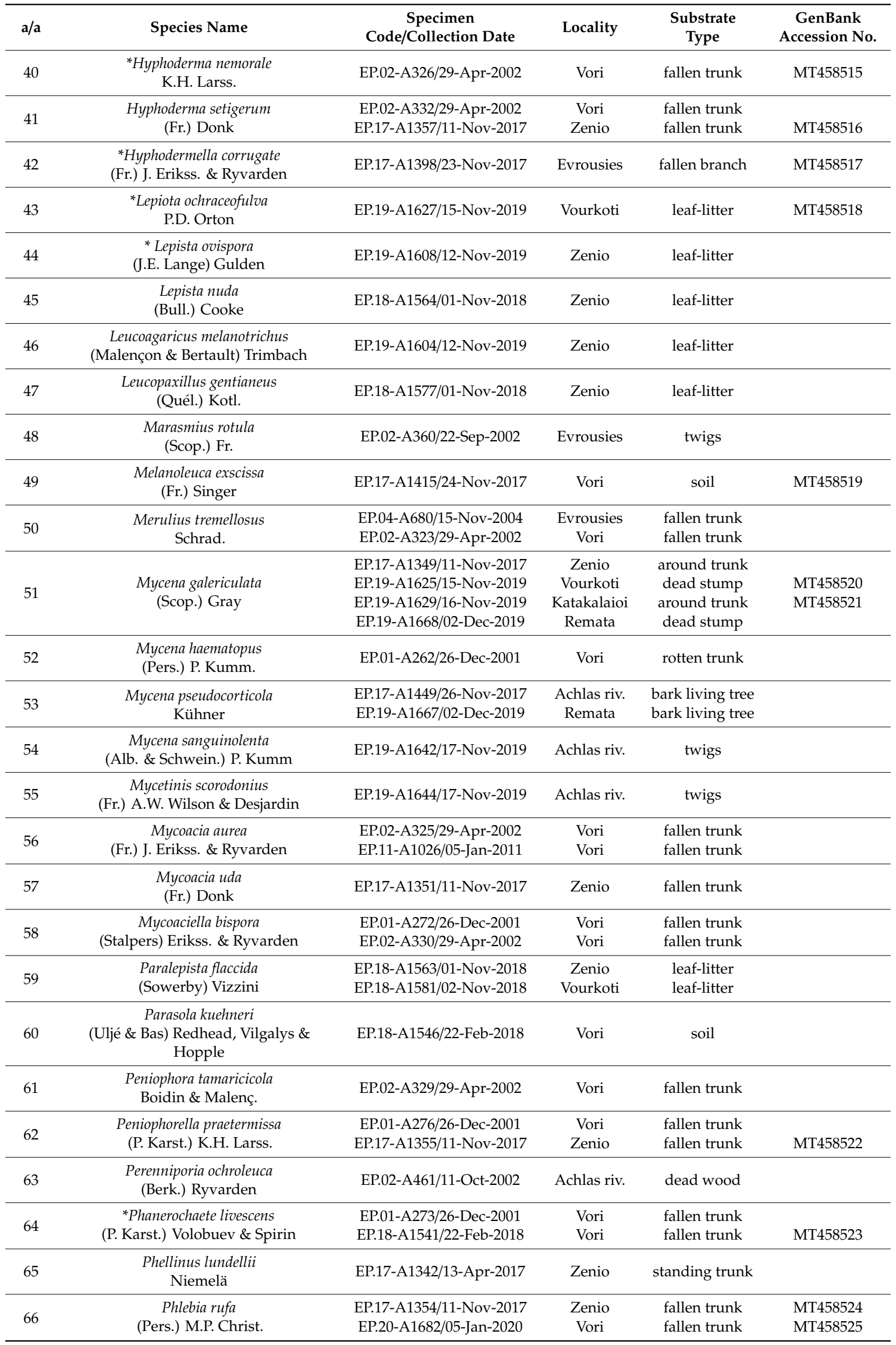


Table 2. Cont

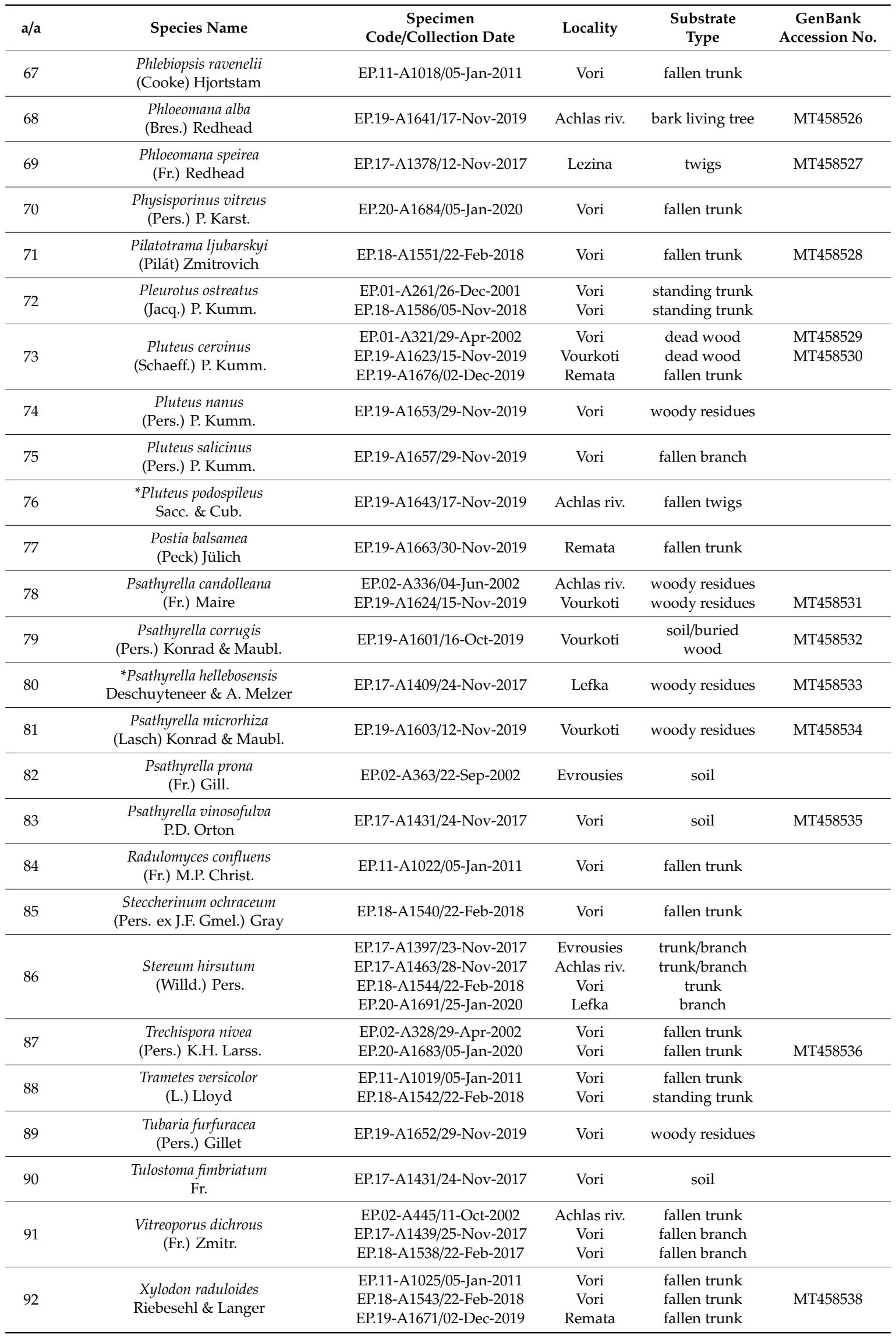




\subsection{The ECM Element}

Among the ECM macrofungi recorded (Table 1), the genus Alnicola is represented by six species (Figure 3); five of them form part of the sect. Alnicola sensu Moreau [45], which is characterized by urticoid cheilocystidia, and one of the sect. Submelinoideae Singer with clavate or capitate cheilocystidia [46].
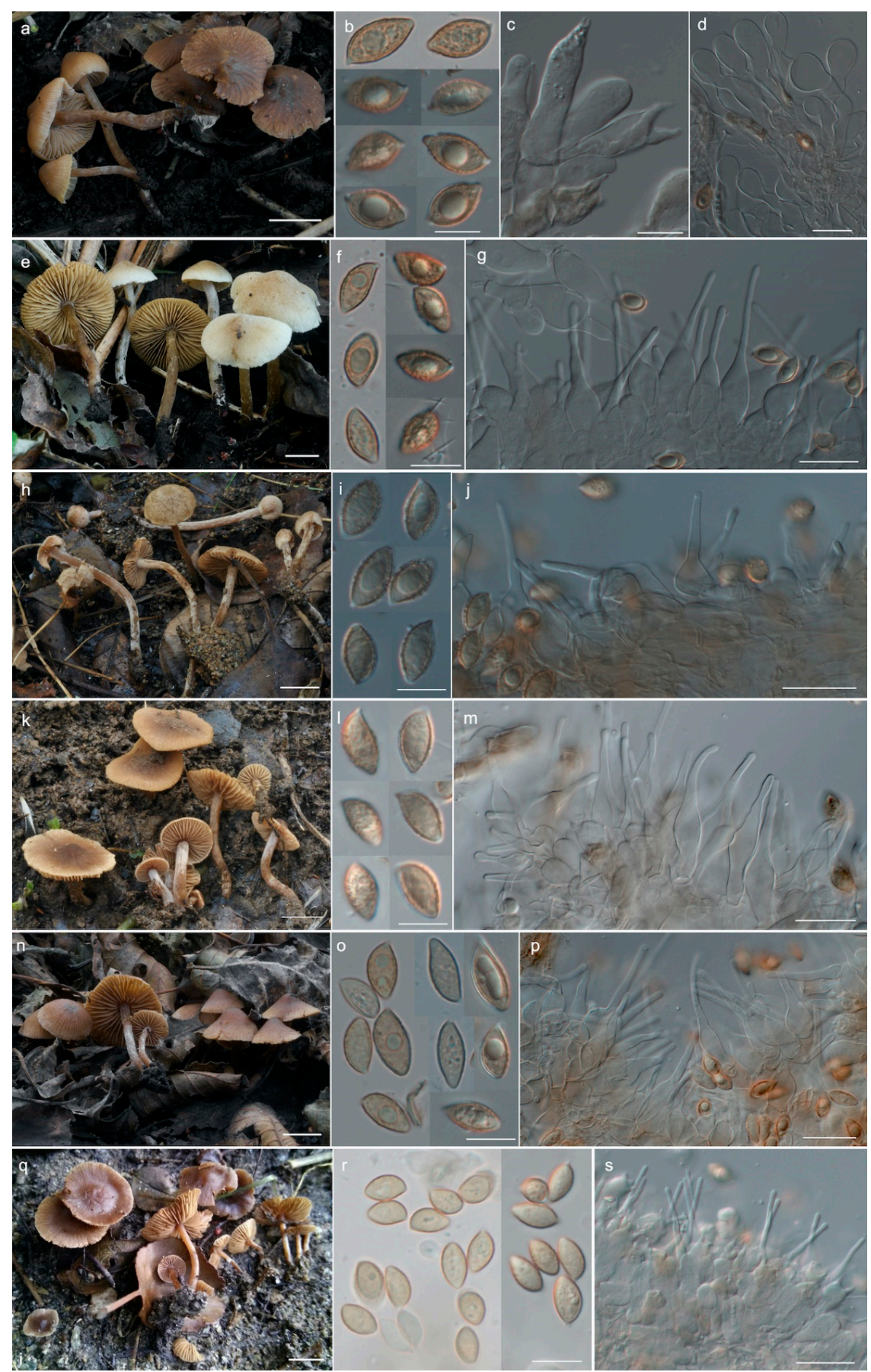

Figure 3. Species of the genus Alnicola recorded in Andros alder stands: A. escharoides basidiomes, basidiospores and cheilocystidia (a-c); A. umbrina basidiomes, basidiospores and cheilocystidia (d-f); A. striatula basidiomes, basidiospores and cheilocystidia (g-i); A. subconspersa basidiomes, basidiospores and cheilocystidia (j-1); A. luteolofibrillosa basidiomes, basidiospores and cheilocystidia (m-o); A. inculta basidiomes, basidiospores, basidia and cheilocystidia (p-s). Bars: basidiomes, $1 \mathrm{~mm}$; basidiospores and basidia, $10 \mu \mathrm{m}$; cheilocystidia, $20 \mu \mathrm{m}$. 
Different opinions exist regarding the genus name in pertinent literature since some European authors as well as the Index Fungorum prefer to conserve the name Naucoria (Fr.) P. Kumm., whereas Moreau, in his nomenclatural revision, rejected this name in favour of Alnicola Kühner [45]; the latter approach is accepted by other European mycologists, the Mycobank, and is also adopted in this work. Moreover, the taxonomy of species of the sect. Alnicola remains problematic and, consequently, a phylogenetic analysis was performed to deal with this issue.

The most often found Alnicola species in our study were A. umbrina (R. Maire) Kühner and A. escharoides (Fr.) Romagn., i.e., two of the most common taxa associated with alders in Europe; both constitute new national records for Greece. Particularly A. escharoides (syn. A. citrinella Moreau \& A. de Haan [47]) is distinguished from all other (more or less brownish) species found in Andros by its pale yellowish-buff non striate pileus, the amygdaliform to navicular spores, with prominent ornamentation, measuring 9.9-11.8 × 5.3-5.9 $\mathrm{m}, \mathrm{Q}=1.9-2.1$ (Figure 3a-c). Following phylogenetic analysis, our specimens are positioned in a distinct group (albeit not adequately supported) together with other sequences from material identified as A. escharoides and A. citrinella (Figure 4).

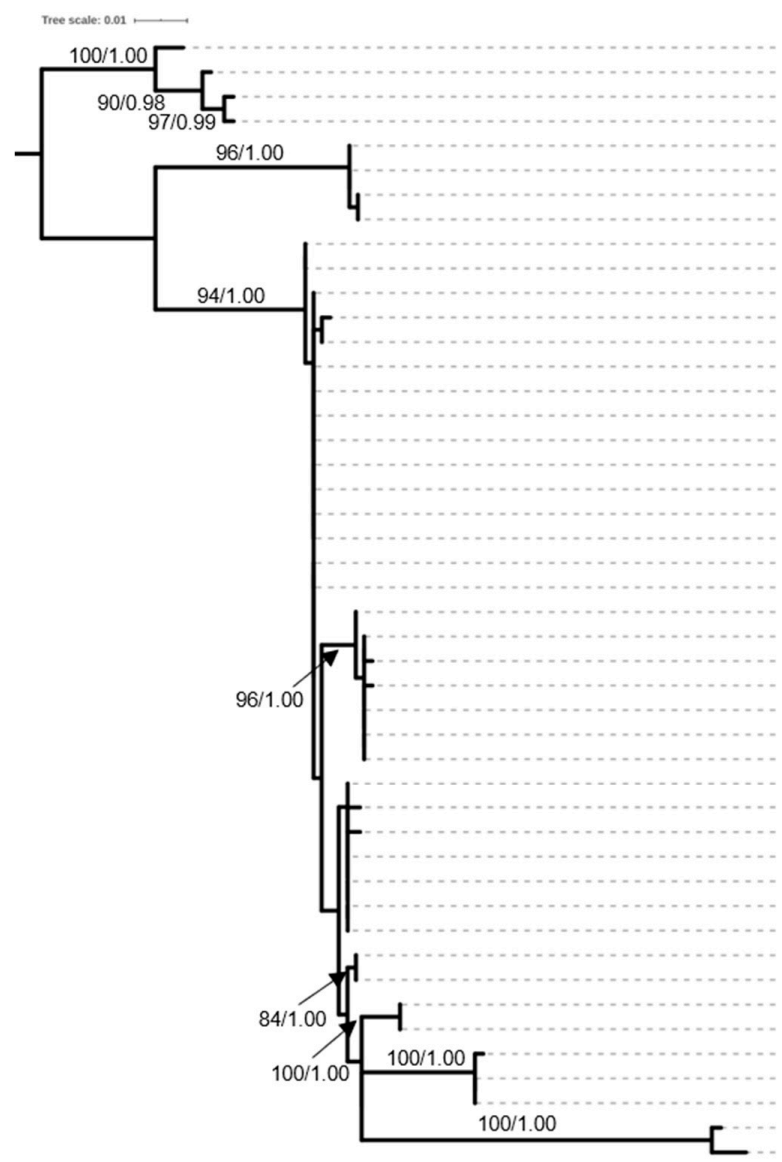

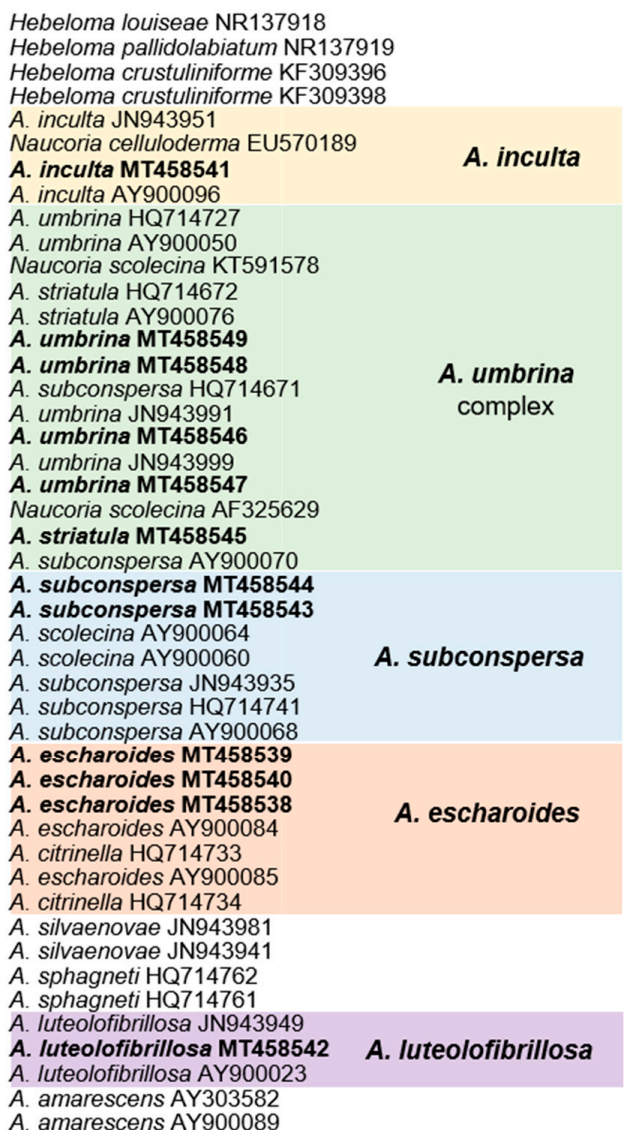

Figure 4. Phylogeny of Alnicola species derived from rDNA ITS sequences through ML analysis. Branches are labelled when MLB $>65 \%$ and BPP $>0.95$. Hebeloma species (H. louiseae, H. pallidolabiatum, H. crustuliniforme) were used as outgroups. Boxes include sequences from specimens recorded in the Alnus glutinosa habitat.

On the other hand, A. umbrina (Figure 3d-f) is hereby considered as a species complex following the nomenclatural concept of Moreau [45] and the outcome of the phylogenetic study by Rochet et al. [19]. According to our observations, $A$. umbrina shows a rather large morphological variability with dark brown hygrophanous pilei bearing prominent striations up to their centre when wet, becoming much lighter and indistinctly striate only at margin when dry. Basidiospores are variable in size and shape, 
often somewhat elongated fusiform, weakly to moderately verrucose, measuring 10.7-13.6 $\times 5.2-6.1 \mu \mathrm{m}$, $\mathrm{Q}=1.9-2.4$. Sequences generated in this work clustered together with material identified as A. umbrina, N. scolecina (Fr.) Quél., A. striatula (P.D. Orton) Romagn. and A. subconspersa (Kühner ex P.D. Orton) Bon into a group that was not adequately supported (Figure 4). However, the morphological features of specimens identified as N. scolecina in Europe are very similar to descriptions of $A$. umbrina [22,33,48,49]. Therefore, N. scolecina and A. umbrina form part of the same complex and the question whether they constitute different entities or not remains open and in need of further research.

One collection representing another closely related taxon, previously reported as N. striatula P.D. Orton (Figure 3g-i) from alder stands in Andros [22], derived from the same site during our recent forays. According to Moreau (2005), A. striatula might merely correspond to a pale form of A. umbrina, but our morphological studies revealed some noteworthy differences when compared to specimens hereby named A. umbrina, i.e., pileus always very prominently striate, smooth and shiny, and (most importantly) significantly smaller basidiospores measuring 8.2-10.0 $\times 4.5-5.6 \mu \mathrm{m}, \mathrm{Q}=1.7-1.9$; these features are in accordance to previous descriptions of $N$. striatula $[33,48,50]$. As evidenced from our phylogenetic analysis (Figure 4), this particular collection forms part of the A. umbrina complex (together with the other two A. striatula sequences included in the tree) by using ITS alone; however, since it is morphologically distinct and fits to the widely accepted taxonomic concept of A. striatula, we provisionally retain it in this inventory as a separate taxon, until a future multigene approach shows otherwise.

A similar looking species to A. umbrina-but less common in Andros-is A. subconspersa (Figure 3j-1). The most prominent distinguishing features versus our $A$. umbrina specimens are the non (or very faintly) striate pileus as well as the size and shape of spores, being wider, amygdaliform to navicular and more prominently ornamented, measuring $10.9-12.9 \times 6.0-6.8 \mu \mathrm{m}, \mathrm{Q}=1.7-2.0$. It is noteworthy that $A$. subconspersa forms a well-supported phylogenetic group including sequences labelled as A. scolecina (Fr.) Romagn. (Figure 4), which is indicative of the morphological affinity of these taxa that had apparently led to the development of ambiguous species concepts.

Another collection representing a member of the sect. Alnicola was recorded in the alluvial littoral forest of Vori; it corresponds to A. luteolofibrillosa Kühner and constitutes the first report of this species in Greece (Figure 3m-o). It is morphologically characterized by non-striate, pale buff, fibrillose to tomentose pilei, with abundant whitish veil remnants on stipe and pileal margin; the respective sequence falls within a highly-supported terminal subgroup corresponding to this species (Figure 4). Lastly, A. inculta (Peck) Singer (Figure 3p-s) was recorded only at Zenio (i.e., the site with the highest altitude among those of this study, $850 \mathrm{~m}$ ) and is reported for the first time in Greece. It forms part of the sect. Submelinoideae, and, according to Moreau [45] is conspecific to the taxon widely referred as N. celluloderma P.D. Orton, as it is also evidenced by our phylogenetic analysis (Figure 4). Morphologically, this species is easily distinguished from all aforementioned taxa thanks to the clavate to capitate cheilocystidia characterizing members of sect. Submelinoideae and the 2-spored basidia.

The most common ECM mushroom in alder stands of Andros belongs to the genus Paxillus; it was the first recorded Alnus-specific symbiont in the island 25 years ago, and was later repeatedly found in this particular habitat (Figure 5a-d). It was initially identified as P. rubicundulus P.D. Orton [22]; however, sequencing of recent collections revealed that it forms part of the newly described taxon P. olivellus Moreau P-A, Chaumeton J-P, Gryta H, Jargeat P [51]. Although clearly separated by molecular approaches, P. olivellus can be hardly distinguished from P. rubicundulus and P. adelphus Chaumeton JP, Gryta H, Jargeat P, Moreau P-A on the basis of morphology alone, i.e., only by the olivaceous tinges of the young basidiomes and the basidiospores shape, which are ovoid to ellipsoid in P. olivellus, cylindrical in P. rubicundulus and short cylindrical in P. adelphus [51]. Such features were observed in our specimens since olivaceous tints were always evident in young basidiomes, and spores were ovoid to ellipsoid measuring 6.7-8.1× 4.5-5.2 $\mu \mathrm{m}, \mathrm{Q}=1.39-1.66$. In addition, ITS sequences from our material originating from various sites in the habitat under study were very similar or identical to those corresponding to P. olivellus (including the type), and formed a terminal subgroup with high 
support (Figure 6). Therefore, this particular species seems to be the only representative of the genus Paxillus in the black alder stands of Andros island.
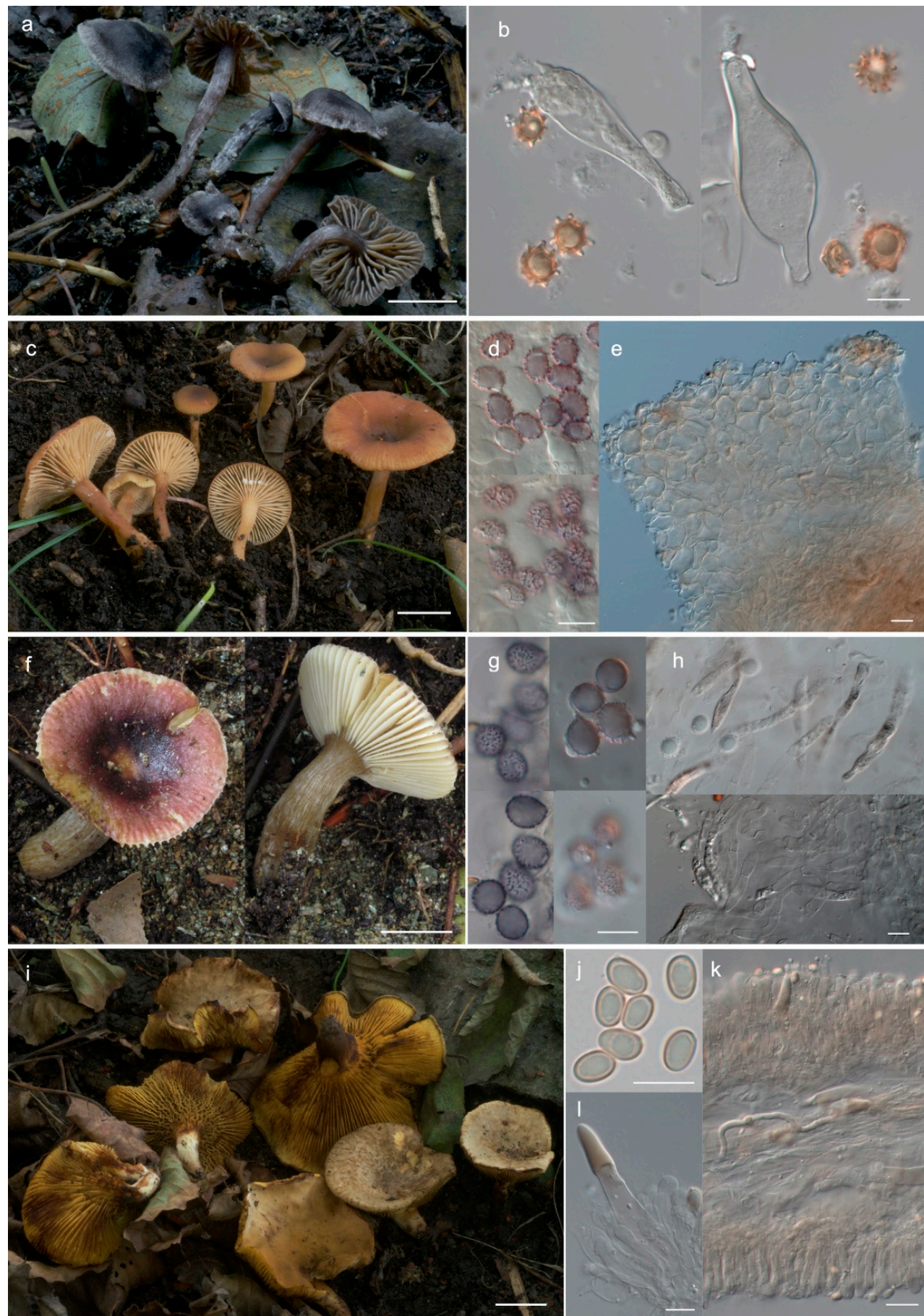

Figure 5. Alder-associated ECM fungi recorded in Andros: Paxillus olivellus basidiomes (a; bar $1 \mathrm{~mm}$ ), basidiospores (b; bar $10 \mu \mathrm{m}$ ), section of lamella (c; bar $20 \mu \mathrm{m})$, hymenial cystidium and basidia (d; bar $20 \mu \mathrm{m})$; Lactarius obscuratus basidiomes (e, bar $1 \mathrm{~mm}$ ), basidiospores (f, bar $10 \mu \mathrm{m})$, pileipellis (g, bar $20 \mu \mathrm{m})$; Russula pumila basidiomes (h, bar $1 \mathrm{~mm}$ ), basidiospores (i, bar $10 \mu \mathrm{m}$ ), pileipellis (j, bar $20 \mu \mathrm{m})$; Cortinarius americanus basidiomes (k, bar $1 \mathrm{~mm})$; Inocybe calospora basidiospores, basidium and pleurocystidium $(\mathbf{l}$, bar $10 \mu \mathrm{m})$. 


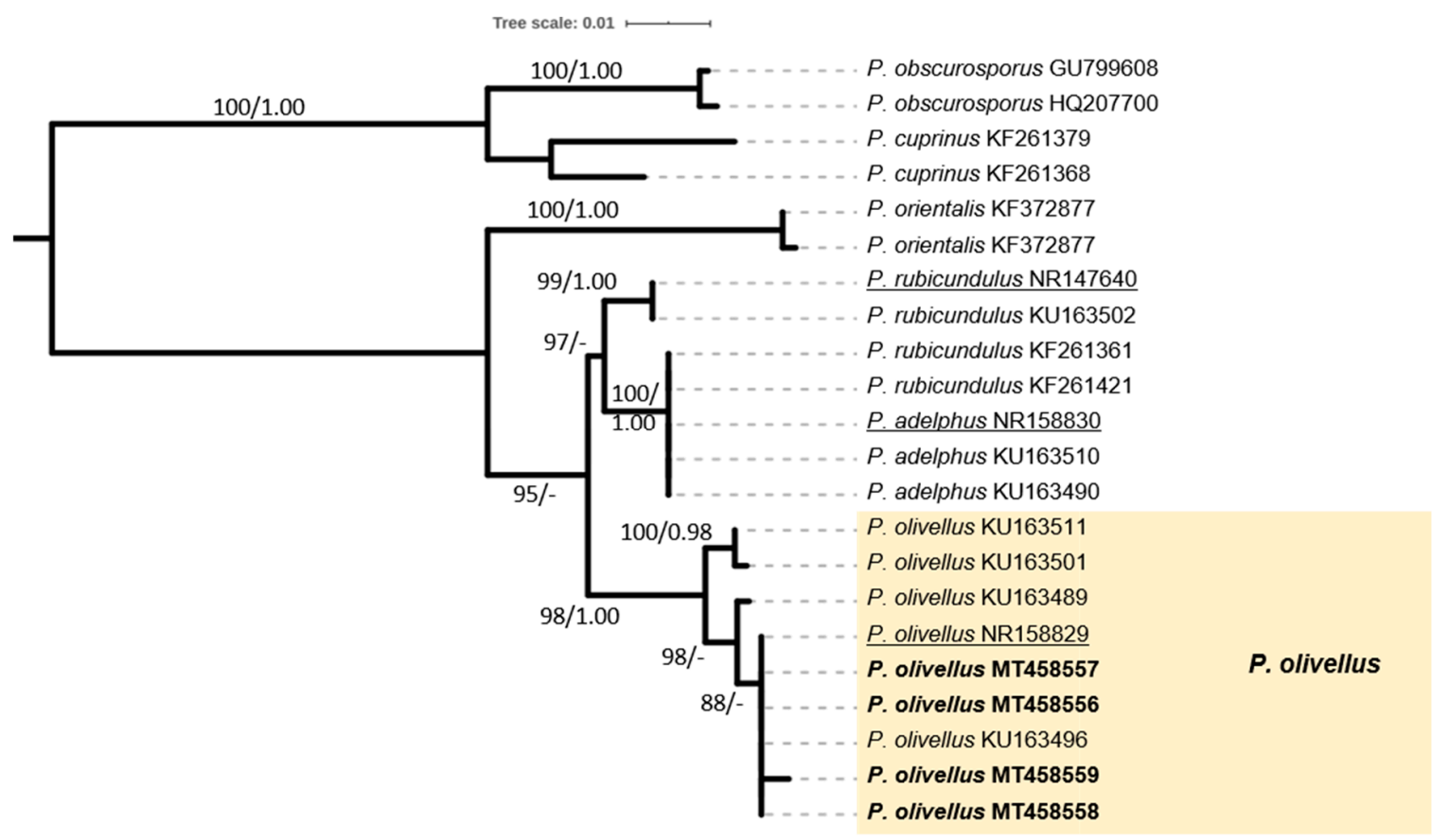

Figure 6. Phylogeny of Paxillus species derived from rDNA ITS sequences through ML analysis. Branches are labelled when MLB $>65 \%$, and BPP $>0.95$. P. cuprinus and P. obscurosporus were used as outgroups. The coloured box includes sequences from specimens recorded in the Alnus glutinosa habitat.

Lactarius obscuratus (Lasch) Fr. is one the few Alnus-specific ECM symbionts of this particular genus; it was found in several inland collection sites dominated by A. glutinosa, but not in the alluvial (littoral) forest of Vori (Figure $5 \mathrm{e}-\mathrm{g}$ ). Phylogenetic analysis of our sequences derived from several collections confirmed that they belong to this particular species (Figure 7). However, the respective terminal subgroup in our phylogenetic tree is composed from sequences named either L. obscuratus or L. cyathuliformis Bon, which is due to the different interpretations existing about this taxon (J. Nuytinck, pers. comm.). In the study of Rochet et al. [19], it is referred as L. cyathuliformis, whereas the correct name for the same group is L. obscuratus according to Wisitrassameewong et al. [52]. Since the basidiospores average size in our collections (measuring 7.6-8.5 $\times 6.1-6.3 \mu \mathrm{m}$ ) is in agreement with the concept of L. obscuratus (sensu Heilmann-Clausen et al. [31]; according to the same authors, spores of L. cyathuliformis have an average size of 8.3-9.9 $\times 7.0-7.7 \mu \mathrm{m}$ ), we adopt this name for the specimens included in this work. The genus Russula Pers. is represented by R. pumila Rouzeau \& F. Massart (Figure $5 \mathrm{~h}-\mathrm{j}$ ) detected in one site only (Vourkoti). Although R. pumila is synonymous to R. alnetorum Romagn. according to both Index Fungorum and Mycobank, there are different opinions about the synonymy of these two taxa and to the best of our knowledge this issue has not been resolved yet (S. Adamcik, pers. comm.). R. pumila is reported to occur mainly in lowlands with A. glutinosa, as opposed to $R$. alnetorum, which is mostly recorded in subalpine habitats with A. viridis [53,54]; therefore, we adopt the use of the former name.

Tomentella sublilacina (Ellis \& Holw.) Wakef. and T. stuposa (Link) Stalpers were previously recorded in Andros (in the alluvial alder forest of Vori; [20]) and identified on the basis of their morphology. These names are provisionally retained here due to the absence of precise taxonomic information concerning alder-specific Tomentella species. It should be noted that the ITS sequences generated in the frame of this work represent phylogenetically distinct taxa corresponding to entities named "aff. sublilacina" and "aff. stuposa" in previous studies referring to material originating from alder hosts only $[18,55]$.

It is noteworthy that the first ever report of an alniphilous Cortinarius species in Greece derives from a single collection of C. americanus A.H. Sm. (Figure 5k), which forms part of a small group of 
species within the subgenus Telamonia (Fr.) Trog known to be associated with A. glutinosa and A. incana in Europe $[33,56]$. C. americanus is characterized by the minute size, pileus not exceeding $2 \mathrm{~cm}$ in diameter, with dark violet to blackish colour, and spores smaller than $10 \times 6 \mu \mathrm{m}[33,56]$; our collection has spores measuring 7.6-8.4 × 4.9-5.6 $\mu \mathrm{m}$.

Last, Inocybe calospora Quél., recorded for the first time in Greece, was collected in Vourkoti only; it is an easily identified species thanks to its unique star-shaped spiny spores (Figure 5). Among all ECM species included in this inventory it is the only one which is not considered to be exclusively associated with alders, and reported from diverse damp deciduous forests of Europe [33,56].

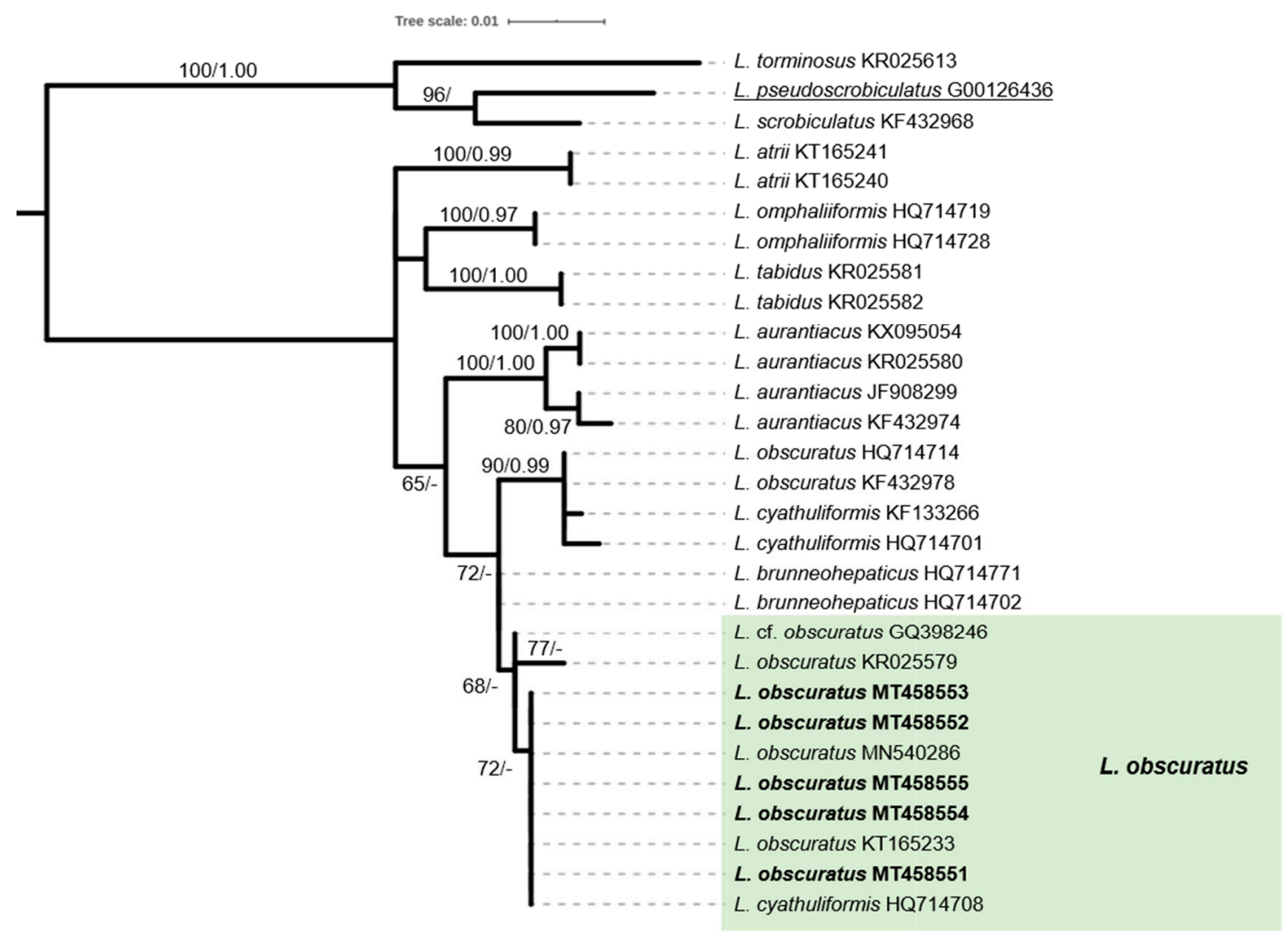

Figure 7. Phylogeny of Lactarius species derived from rDNA ITS sequences through ML analysis. Branches are labelled when MLB $>65 \%$, and BPP $>0.95$. L. torminosus, L. scrobiculatus and L. pseudoscrobiculatus were used as outgroup. The colored box includes sequences from specimens recorded in the Alnus glutinosa habitat.

\subsection{The Saproxylic Element}

By far the highest number of species recorded in this inventory correspond to white-rot and brown-rot basidiomycetes found on various wood parts of A. glutinosa (Table 2). This is quite anticipated since alder trees have a life-span which rarely exceeds 100 years; therefore, they produce large amounts of dead wood. Moreover, in contrast to ECM species, wood-rotting fungi do not show any specificity to alders, with only few exceptions including the common in northern Europe plant-pathogenic polypore Inonotus radiatus (Sowerby) P. Karst. [15,57-60], which, however, was not among our findings. Most of the recorded species are wood rotting basidiomycetes that are quite common throughout Europe on deciduous tree species including alders [13,61,62]. The best represented genera of saproxylic fungi were Hyphoderma Wallr. (three spp.), Mycena (Pers.) Roussel (four spp.), Pluteus Fr. (four spp.) and Psathyrella (Fr.) Quél. (four spp. on woody residues or buried wood). In total, seven species recorded on dead wood or bark of living alder trees are recorded for the first time in Greece and are presented in more detail below. 
Among corticioid basidiomycetes, Hyphoderma nemorale K.H. Larss. is a distinct, widely distributed but rare species in Europe [35], which was identified by re-examining an old collection from Vori alluvial forest and further confirmed by ITS sequencing. The presence of thick-walled subicular hyphae and of two types of hymenial cystidia (i.e., short ventricose and subcapitate, and more seldom long tubular with characteristic constrictions, sometimes moniliform, which was the case in our specimen) are the main diagnostic features of this species [63]. Hyphodermella corrugata (Fr.) J. Erikss. \& Ryvarden (Figure 8a) is fairly common and widespread in Europe [35]. It is easily identified thanks to its characteristic cystidioid hyphal ends appearing in bundles that are heavily incrusted [24]. Phanerochaete livescens (P. Karst.) Volobuev \& Spirin (Figure 8b) is a species closely related to Ph. sordida (P. Karst.) J. Erikss. \& Ryvarden which was recently described by using both morphological and phylogenetic criteria [64]. In accordance to the pertinent description, our specimens possessed cystidia with thickened walls to the acute apex, densely covered by crystals, as opposed to the accidentally encrusted, obtuse and thin-walled towards the apex cystidia of Ph. sordida. Moreover, the identity of our specimen was confirmed by the respective ITS sequence which was identical to those of Ph. livescens as determined by Volobuev et al. [64].

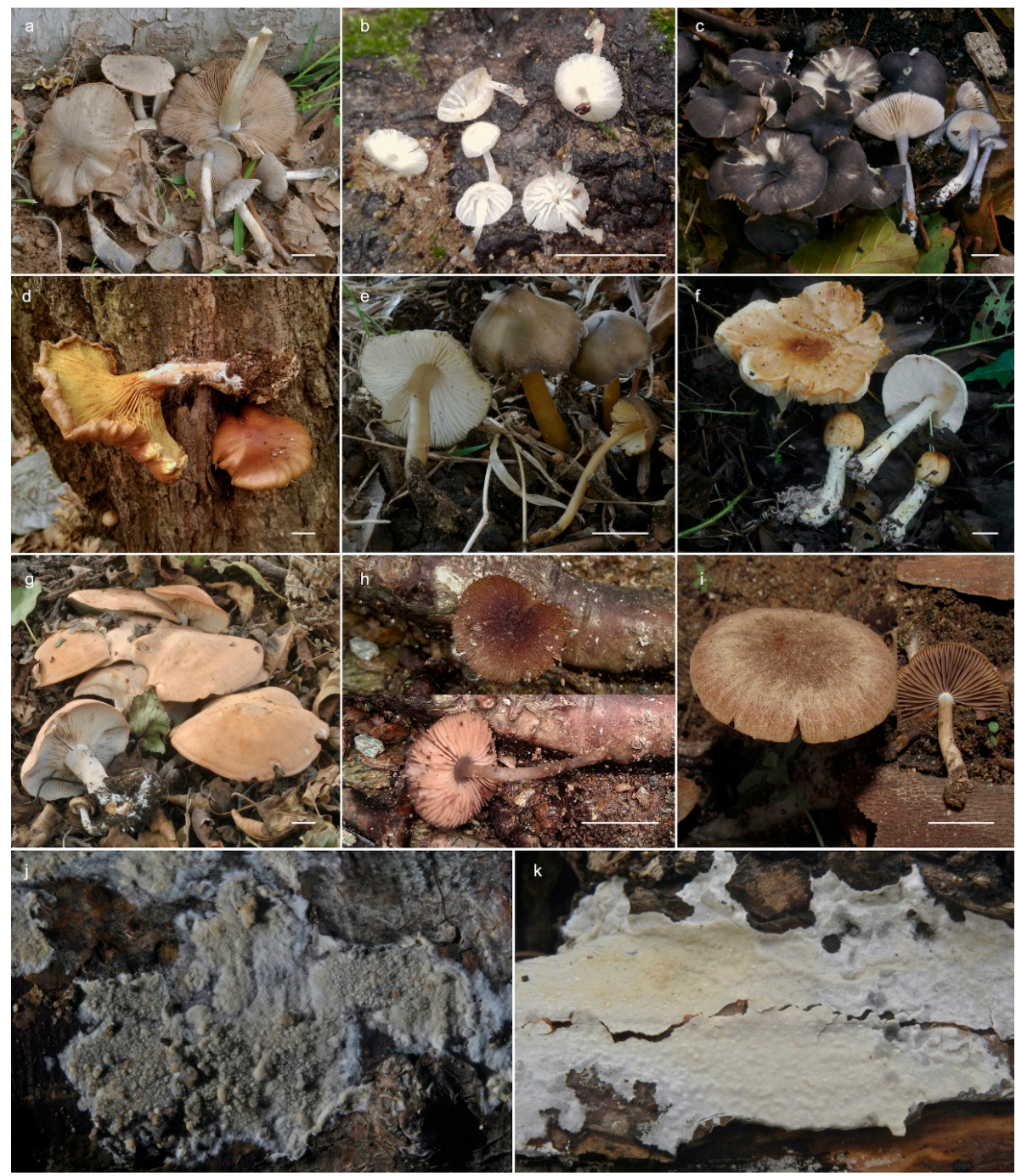

Figure 8. Saproxylic species recorded on Alnus glutinosa wood and litter in Andros: Hyphodermella corrugata (a) Phanerochaete livescens (b) Pluteus podospileus (c) Delicatula integrella (d) Coprinopsis melanthina (e) Gymnopilus arenophilus (f) Hydropus floccipes (g) Lepiota ochraceofulva (h) Lepista ovispora (i) Psathyrella hellebosensis (j) Entoloma uranochroum (k) Bar: $1 \mathrm{~mm}$. 
Among the agaricoid wood-inhabiting fungi, the genus Pluteus Fr. is hereby represented by four species, of which P. podospileus Sacc. \& Cub. (Figure 8c) is reported for the first time in Greece. It belongs to the sect. Celluloderma Fay. subsection Mixtini Sing. ex Sing, and possesses a pileipellis made up of both fusiform and broadly clavate elements. P. thomsonii (Berk. \& Broome) Dennis is very similar morphologically but it differs in the absence of pleurocystidia and the shape of cheilocystidia, which are characteristically rostrate [65]. The record of Delicatula integrella (Pers.) Rat. (Figure 8d) is worth mentioning since it was reported only once before in Greece, in the content of a regional field-guide [66]. D. integrella forms whitish-mycenoid mushrooms of minute size with pileus diameter measuring (in our specimens) $0.4-0.6 \mathrm{~cm}$, reduced, almost vein-like lamellae and non-amyloid, amygdaliform-fusoid spores. It is considered widespread and common in Europe and $\mathrm{N}$. America, and grows on decaying wood and wood debris of deciduous trees [34]. Coprinopsis melanthina (Fr.) Örstadius \& E. Larss. (Figure 8e) is a striking-looking psathyrelloid species, easily identified due to the relatively large basidiomes with wooly to squamulose pileus (measuring $2-6 \mathrm{~cm}$ in diam.) and stipe (up to $6.0 \times 0.8 \mathrm{~cm}$ ), absence of pleurocystidia, almost colourless basidiospores, devoid of germ-pore, measuring 9.8-11.8(13.5) $\times 5.6-6.5 \mu \mathrm{m}$ in our collections. This is a rather uncommon European species growing on and around rotten stumps in humid deciduous forests [33]; the only other record of this species in Greece derives from Crete (G. Konstandinidis, pers. comm.).

Gymnopilus arenophilus A. Ortega \& Esteve-Rav. (Figure 8f) was described from continental areas of Spain [67] and from maritime dunes in France, under or near Mediterranean pines, on sandy soil by being attached to wood debris or wood, often burnt or buried in the sand [68]. Two of our collections from the alluvial A. glutinosa habitat at Lefka were sequenced and found to correspond to this species. Apparently, no native pines exist in Andros while both specimens were growing on rotten alder stumps, a fact that largely expands the so far known ecological and geographical range of this Mediterranean species. Morphologically, our specimens possessed features that fit well to the taxonomic concept of G. arenophilus i.e., smooth to fibrillose pileal surface, bitter taste, ellipsoid to subamygdaliform, moderately verrucose spores, measuring 8-10 $\times 5.5-6.5 \mu \mathrm{m}$, lageniform cheilocysidia often with subcapitate apex, 25-45 $\times 5-8 \mu \mathrm{m}$ and absence of pleurocystidia. On the other hand, the size of basidiomes was significantly larger, with pilei up to $10 \mathrm{~cm}$ in diam. and a sturdy stipe often thicker than $1 \mathrm{~cm}$. One previous collection of ours also found on rotten alder stump, and originally identified as G. picreus (Pers.) P. Karst. [22], is now re-assessed as G. arenophilus.

Hydropus floccipes (Fr.) Singer (Figure 8g) is a rare mycenoid species generally found to grow on decayed trunks of deciduous trees in damp forests, and is characterized by non-amyloid, subglobose spores, not blackening basidiomes, and typically scabrous stipe with grey-brown spots [33,69]. In addition, our specimens possessed yellowish stipe, previously reported for $H$. floccipes var. luteipes Ortega \& Zea described from Spain [70]; the latter is otherwise microscopically identical and of unknown phylogenetic status. Two unpublished reports of $H$. floccipes exist from Greece (D. Sofronis and G. Konstandinidis, pers. comm.).

\subsection{Litter and Other Terrestrial Decomposers}

Apart ECM and saproxylic fungi, several other mushroom species were recorded under black alder trees, and therefore constitute a part of the fungal diversity of the A. glutinosa priority habitat in Andros. Needless to say, none of these species is specifically linked to alders; instead they are considered 'generalists' to be found in both deciduous and coniferous forests. Among them, the following four species are recorded for the first time in Greece. Lepiota ochraceofulva P.D. Orton (Figure 8h) is a rather rare (but widespread) species in Europe, reported from Fagus and other deciduous trees on humus-rich, loamy soil [71,72]; it forms highly toxic mushrooms containing amanitins. Our single collection consisted of few basidiomes growing on a thick layer of leaf-litter under A. glutinosa. They are characterized by pilei of up to $7 \mathrm{~cm}$ in diam., with orange-brown scales; lamellae forming a distinct collarium and reddish-orange in maturity; spores ellipsoid to oblong, dextrinoid, not metachromatic in cresyl-blue, measuring 5.4-7.5(8.1) $\times 3.5-4(4.5) \mu \mathrm{m}$; basidia (2)4-spored, clamped; cheilocystidia short 
clavate to cylindrical, rarely papilate, often in chains; pileipellis, a hymeniderm, composed of more or less clavate elements up to $50 \mu \mathrm{m}$ long.

Lepista ovispora (J.E. Lange) Gulden (Figure 8i) is an uncommon (albeit widespread) European species recorded only once during this study on leaf litter under alders. Typical diagnostic features are the densely caespitose habit, the relatively fleshy basidiomes, the brown hygrophanous pileus with pruinose surface [73]. In addition, our specimens possessed spores ovoid to broadly ellipsoid, finely punctate, 4.7-6.8 $\times 3.8-4.4 \mu \mathrm{m}$, clamped basidia and no cystidia. Psathyrella hellebosensis D. Deschuyteneer, A. Melzer (Figure 8j) was recently described from Belgium [74] and was later reported from riparian alder habitats in Italy [75]. The morphological features of our collection are in agreement with the morphology of Belgian and Italian basidiomes, but since it corresponds to a rarely reported species, a detailed description of our material is hereby provided: pileus up to $3 \mathrm{~cm}$ in diam., hygrophanous from dark reddish-brown to greyish-beige, with scanty remains of veil; lamellae subdistant with whitish edge; stipe $2-4 \times 0.2-0.3 \mathrm{~cm}$, not rooting; spores 7.3-8.7 $\times 4.5-5.7 \mu \mathrm{m}$, $\mathrm{Q}=1.43-1.73$, ovoid to angular in face-view and not or weakly phaseoliform in side-view, not opaque; lamellae edge sterile composed exclusively of sphaeropendunculate paracystidia (no pleurocystidioid paracystidia were observed); pleurocystidia 34-48 $\times 11-17 \mu \mathrm{m}$, utriform. The material was collected from wet soil by the alluvial stream banks. This species shows high phylogenetic affinity to $P$. thujina A. H. Sm. by using ITS sequences only; however, it is clearly separated when the tef- $1 \alpha$ marker is added in the phylogenetic analysis, while it is also distinguished by its distinctly larger and prominently phaseoliform spores [75].

Previous studies on the mycodiversity of Andros island reported the occurrence of four Entoloma species, one of them was new to science, i.e., E. alnicola Noordel. \& Polemis [22,25]. Our recent field work resulted in other interesting collections of Entoloma spp. for which the identity and phylogenetic relationships to closely allied taxa are still under investigation. However, by using morphology alone, the presence of a rare European species was confirmed, namely E. uranochroum Hauskn. \& Noordel. (Figure 8k) recorded for the first time in an alder habitat. This beautiful dark blue-violet mushroom was so far reported from subalpine meadows on calcareous soil in Austria (type locality) and the French Alps. Moreover, its striking microscopical features, e.g., the large fusiform cheilocystidida with granular yellowish-brown content, place it in the distinct section Ramphocystotae (Largent) Noordel., together with only one other European representative, namely E. rhynchocystidiatum Noordel. \& Liiv [76].

\section{Conclusions}

A long-term study of the diversity of macrofungi in alder stands of Andros resulted in an inventory consisting of 106 species of basidiomycetes, including 21 taxa recorded for the first time in Greece. The majority of findings corresponded to saprotrophs (\#92, mainly wood-rotting fungi) and the rest were ECM species. Considering the limited size of the area under study in a small Aegean island, the outcome of this work in terms of the number of taxa and variability is indicative of the wealth of the A. glutinosa priority habitat. However, the black alder stands in Andros have suffered considerably from floods in the past (as a consequence of fires that destroyed vegetation in the surrounding mountains which acted as a physical barrier protecting from downhill water runoffs) and their regeneration is hindered due to grazing by feral goats. The importance of fungi in the conservation/restoration of such natural habitats was demonstrated in the past [77,78], and recent activities focus at improving the status of the degenerated alder stands by exploiting indigenous ECM fungi as inoculants to young alder seedlings prior to their transplantation on site. Moreover, new knowledge about mushroom diversity and the ecological role of this group of organisms seems to enhance considerably people's perception and awareness, and hence facilitates implementation of conservations actions which are currently under way in selected alder stands of Andros. 
Supplementary Materials: The following is available online at http://www.mdpi.com/1424-2818/12/6/232/s1, Table S1: Details of the 10 sampling sites in Andros island from where basidiomes were collected: locality name, coordinates, altitude (m a.s.l.) and surface of the study area $\left(\mathrm{m}^{2}\right)$.

Author Contributions: Conceptualization, E.P. and G.Z.; methodology, E.P., G.I.Z., V.D. and V.F.; validation, E.P., V.D. and V.F.; formal analysis, E.P., G.I.Z. and V.F.; investigation, E.P., G.I.Z., V.D. and V.F.; data curation, E.P., G.I.Z. and V.F.; writing — original draft preparation, E.P.; writing — final draft, G.I.Z.; review and editing—final draft, E.P., G.I.Z., V.D. and V.F.; supervision, G.I.Z.; project administration, G.I.Z.; and funding acquisition, G.I.Z. All authors have read and agreed to the published version of the manuscript.

Funding: This study was funded by the project titled "Conservation of priority species and habitats of Andros Island protected area integrating socioeconomic considerations" (European Commission - LIFE-Nature, LIFE16 NAT/GR/000606).

Acknowledgments: We would like to thank V. Goritsas for the preparation of the map figures included in this work, and S. Adamcik, B. Dima, M. Noordeloos and J. Nuytinck for helpful discussions on some of the findings of this study.

Conflicts of Interest: The authors declare no conflict of interest.

\section{References}

1. Kajba, D.; Gračan, J. EuFORGEN Technical Guidelines for Genetic Conservation and Use for Black Alder (Alnus glutinosa); Bioversity International: Rome, Italy, 2003; pp. 1-6.

2. Karl, T.R.; Trenberth, K.E. Modern Global Climate Change. Science 2003, 302, 1719-1723. [CrossRef] [PubMed]

3. McEwan, N.R.; Wilkinson, T.; Girdwood, S.E.; Snelling, T.J.; Collins, T.; Dougal, K.; Jones, D.L.; Godbold, D.L. Evaluation of the microbiome of decaying alder nodules by next generation sequencing. Endocyt. Cell Res. 2017, 28, 14-19.

4. Roy, M.; Pozzi, A.C.; Gareil, R.; Nagati, M.; Manzi, S.; Nouioui, I.; Sharikadze, N.; Jargeat, P.; Gryta, H.; Moreau, P.-A.; et al. Alder and the Golden Fleece: High diversity of Frankia and ectomycorrhizal fungi revealed from Alnus glutinosa subsp. barbata roots close to a Tertiary and glacial refugium. PeerJ 2017, 5, e3479. [CrossRef] [PubMed]

5. Orfanoudakis, M.Z.; Hooker, J.E.; Wheeler-Jones, C.T. Early interactions between arbuscular mycorrhizal fungi and Frankia during colonisation and root nodulation of Alnus glutinosa. Symbiosis 2004, 36, 69-82.

6. Põlme, S.; Öpik, M.; Moora, M.; Zobel, M.; Kohout, P.; Oja, J.; Kõljalg, U.; Tedersoo, L. Arbuscular mycorrhizal fungi associating with roots of Alnus and Rubus in Europe and the Middle East. Fungal Ecol. 2016, 24, 27-34. [CrossRef]

7. Harley, J.L.; Smith, S.E. Mycorrhizal Symbiosis; Academic Press: London, UK, 1983; pp. 1-483.

8. Pritsch, K.; Munch, J.C.; Buscot, F. Characterization and identification of black alder ectomycorrhizas by PCR/RFLP analyses of the rDNA internal described spacer (ITS). New Phytol. 1997, 137, 357-369. [CrossRef]

9. Pritsch, K.; Munch, J.C.; Buscot, F. Morphological and anatomical characterisation of black alder Alnus glutinosa (L.) Gaertn. ectomycorrhizas. Mycorrhiza 1997, 7, 201-216. [CrossRef]

10. Boyle, H. Aspekte der Macromycetenflora dreier Erlenbrücher Norddeutschlands und vergleichende PCR/RFLP- Analyse ausgewählter ectomycorrhizaler Mycobionten. EcoSys Suppl. 1996, 10, 1-106.

11. Brunner, I.; Horak, E. Mycoecological analysis of Alnus associated macrofungi in the region of the Swiss National Park as recorded by J. Favre (1960). Mycol. Helv. 1990, 4, 111-139.

12. Bujakiewicz, A.M. Macrofungi in the alder and alluvial forests in various parts of Europe and North America. Opera Bot. 1989, 100, 29-41.

13. Kunttu, P.; Kotiranta, H.; Kulju, M.; Pasanen, H.; Kouki, J. Occurrence patterns, diversity and ecology of aphyllophoroid fungi on the black alder (Alnus glutinosa) in an archipelago in the Baltic Sea. Ann. Bot. Fenn. 2016, 53, 173-193. [CrossRef]

14. Senn-Irlet, B.; Mürner, R.; Martini, E.; Küffer, N.; de Marchi, R.; Bieri, G. Saprobic fungi on wood and litter of Alnus alnobetula in the Swiss Alps. Mycotaxon 2012, 120, 506.

15. Strid, Å. Wood-inhabiting fungi of alder forests in north-central Scandinavia 1. Aphylloporales (Basidiomycetes). Taxonomy, ecology and distribution. Wahlenbergia 1975, 1, 1-237.

16. Griesser, B. Mykosoziologie der Grauerlen-und Sanddorn-Auen (Alnetum incanae, Hippophaëtum) am Hinterrhein (Domleschg, Graubünden, Schweiz). Ver. Geobot. Inst. ETH 1992, 109, 1-235.

17. Molina, R. Ectomycorrhizal specificity in the genus Alnus. Can. J. Bot. 1981, 59, 325-334. [CrossRef] 
18. Tedersoo, L.; Suvi, T.; Jairus, T.; Ostonen, I.; Põlme, S. Revisiting ectomycorrhizal fungi of the genus Alnus: Differential host specificity, diversity and determinants of the fungal community. New Phytol. 2009, 182, 727-735. [CrossRef]

19. Rochet, J.; Moreau, P.-A.; Manzi, S.; Gardes, M. Comparative phylogenies and host specialization in the alder ectomycorrhizal fungi Alnicola, Alpova and Lactarius (Basidiomycota) in Europe. BMC Evol. Biol. 2011, 11, 40. [CrossRef]

20. Dimou, D.M.; Polemis, E.; Zervakis, G.I. Macromycetes associated with Alnus glutinosa in Greece. Phytopathol. Mediterr. 2006, 45, 78.

21. Dimou, D.M.; Zervakis, G.I.; Polemis, E. Mycodiversity studies in selected ecosystems of Greece: IV. Macrofungi from Abies cephalonica forests and other intermixed tree species. (Oxya mountain, central Greece). Mycotaxon 2008, 104, 39-42.

22. Polemis, E.; Dimou, D.M.; Tzanoudakis, D.; Zervakis, G.I. Diversity of Basidiomycota (subclass Agaricomycetidae) in the island of Andros (Cyclades, Greece). Nova Hedwig. 2012, 95, 25-58. [CrossRef]

23. Polemis, E.; Dimou, D.; Zervakis, G.I. The family Hymenochaetaceae (Agaricomycetes, Basidiomycota) in the islands of the Aegean Archipelago (Greece). Plant Biosyst. 2013, 147, 306-314. [CrossRef]

24. Polemis, E.; Roberts, P.; Dimou, D.M.; Zervakis, G.I. Heterobasidiomycetous fungi from Aegean Islands (Greece): New annotated records for a neglected group. Plant Biosyst. 2016, 150, 295-303. [CrossRef]

25. Noordeloos, M.; Polemis, E. Studies in the genus Entoloma (Basidiomycetes, Agaricales) from the Kiklades (C. Aegean, Greece). Mycotaxon 2008, 105, 301-312.

26. Eriksson, J.; Ryvarden, L. The Corticiaceae of North Europe, Vol. 4: Hyphodermella-Mycoacia; Fungiflora: Oslo, Norway, 1976; pp. 549-886.

27. Bas, C.; Kuyper, T.W.; Noordeloos, M.E.; Vellinga, E.C. (Eds.) Flora Agaricina Neerlandica; A. A. Balkema: Rotterdam, The Netherlands, 1990; Volume 2, pp. 1-137.

28. Bas, C.; Kuyper, T.W.; Noordeloos, M.E.; Vellinga, E.C. (Eds.) Flora Agaricina Neerlandica; A. A. Balkema: Rotterdam, The Netherlands, 1995; Volume 3, pp. 1-183.

29. Bas, C.; Kuyper, T.W.; Noordeloos, M.E.; Vellinga, E.C. (Eds.) Flora Agaricina Neerlandica; A. A. Balkema: Rotterdam, The Netherlands, 1999; Volume 4, pp. 1-191.

30. Noordeloos, M.E.; Kuyper, T.W.; Vellinga, E.C. (Eds.) Flora Agaricina Neerlandica; A. A. Balkema: Rotterdam, The Netherlands, 2001; Volume 5, pp. 1-170.

31. Heilmann-Clausen, J.; Verbeken, A.; Vesterholt, J. The Genus Lactarius. Fungi of Northern Europe; Danish Mycological Society, Svampetryk: Copenhagen, Denmark, 1998; Volume 2, pp. 1-287.

32. Bernicchia, A. Polyporaceae S.L.; Candusso: Alassio, Italy, 2005; pp. 1-808.

33. Knudsen, H.; Vesterholt, J. (Eds.) Funga Nordica. Agaricoid, Boletoid and Cypheloid Genera; Nordsvamp: Copenhagen, Denmark, 2008; pp. 1-965.

34. Antonín, V.; Noordeloos, M.E. A Monograph of Hemimycena, Delicatula, Fayodia, Gamundia, Myxomphalia, Resinomycena, Richenella and Pseudomphalina (Tribus Mycenae Sensu Singer, Mycena Excluded); IHW Verlag: Eching, Germany, 2004; pp. 1-279.

35. Bernicchia, A.; Gorjón, S.P. Corticiaceae S.L.; Candusso: Alassio, Italy, 2010; pp. 1-1008.

36. Aronsen, A.; Læssøe, T. The Genus Mycena. Fungi of Northern Europe; Svampetryk: Copenhagen, Denmark, 2016; Volume 5, pp. 1-373.

37. White, T.J.; Bruns, T.; Lee, S.; Taylor, J.W. Amplification and direct sequencing of fungal ribosomal RNA genes for phylogenetics. In PCR Protocols: A Guide to Methods and Applications; Innis, M.A., Gelfand, D.H., Sninsky, J.J., White, T.J., Eds.; Academic Press Inc.: New York, NY, USA, 1990; pp. 315-322.

38. Hall, T.A. BioEdit: A User-Friendly Biological Sequence Alignment Editor and Analysis Program for Windows 95/98/NT. Nucleic Acids Symp. Ser. 1999, 41, 95-98.

39. Katoh, K.; Rozewicki, J.; Yamada, K.D. MAFFT online service: Multiple sequence alignment, interactive sequence choice and visualization. Brief Bioinform. 2019, 20, 1160-1166. [CrossRef]

40. Kumar, S.; Stecher, G.; Li, M.; Knyaz, C.; Tamura, K. MEGA X: Molecular Evolutionary Genetics Analysis across computing platforms. Mol. Biol. Evol. 2018, 35, 1547-1549. [CrossRef] [PubMed]

41. Stamatakis, A.; Hoover, P.; Rougemont, J. A rapid bootstrap algorithm for the RAxML Web servers. Syst. Biol. 2008, 57, 758-771. [CrossRef] 
42. Ronquist, F.; Teslenko, M.; van der Mark, P.; Ayres, D.L.; Darling, A.; Höhna, S.; Larget, B.; Liu, L.; Suchard, M.A.; Huelsenbeck, J.P. MrBayes 3.2: Efficient Bayesian phylogenetic inference and model choice across a large model space. Syst. Biol. 2012, 61, 539-542. [CrossRef]

43. Darriba, D.; Taboada, G.L.; Doallo, R.; Posada, D. jModelTest 2: More models, new heuristics and parallel computing. Nat. Methods 2012, 9, 772. [CrossRef] [PubMed]

44. Letunic, I.; Bork, P. Interactive tree of life (iTOL) v3: An online tool for the display and annotation of phylogenetic and other trees. Nucleic Acids Res. 2016, 44, W242-W245. [CrossRef] [PubMed]

45. Moreau, P.-A. A nomenclatural revision of the genus Alnicola (Cortinariaceae). Fungal Divers. 2005, 20, 121-155.

46. Moreau, P.-A.; Peintner, U.; Gardes, M. Phylogeny of the ectomycorrhizal mushroom genus Alnicola (Basidiomycota, Cortinariaceae) based on rDNA sequences with special emphasis on host specificity and morphological characters. Mol. Phylogen. Evol. 2006, 38, 794-807. [CrossRef]

47. De Haan, A.; Moreau, P.-A. Waarnemingen in het genus Alnicola (Zompzwam) in Vlaanderen (3). Steerbeckia 2012, 31, 3-15.

48. Moser, M. Keys to Agarics and Boleti; R. Phillips: Tonbridge, UK, 1983; pp. 1-535.

49. Horak, E. Röhrlinge und Blätterpilze in Europa-Unter der Mitarbeit von Anton Hausknecht (Bolbitiaceae) und P.A. Moreau (Alnicola); Elsevier Spektrum Akademischer: Heidelberg, Germany, 2005; pp. 1-557.

50. Henrici, A. Keys to Naucoria in Britain. Field Mycol. 2009, 9, 55-62. [CrossRef]

51. Jargeat, P.; Moreau, P.-A.; Gryta, H.; Chaumeton, J.P.; Gardes, M. Paxillus rubicundulus (Boletales, Paxillaceae) and two new alder-specific ectomycorrhizal species, Paxillus olivellus and Paxillus adelphus, from Europe and North Africa. Fungal Biol. 2016, 120, 711-728. [CrossRef]

52. Wisitrassameewong, K.; Looney, B.P.; Le, H.T.; De Crop, E.; Das, K.; Van de Putte, K.; Eberhardt, U.; Jiayu, G.; Stubbe, D.; Hyde, K.D.; et al. Lactarius subgenus Russularia (Basidiomycota, Russulales): Novel Asian species, worldwide phylogeny and evolutionary relationships. Fungal Biol. 2016, 120, 1554-1581. [CrossRef] [PubMed]

53. Galli, R. Le Russule. Atlante Pratico-Monografico per la Determinazione delle Russule; Dalla Natura: Milano, Italy, 2003; pp. 1-480.

54. Floriani, M.; Partacini, G. Sull'identità di Russula puellaris var. leprosa. Boll. Gruppo Micol. G. Bres. 1998, 40, 213-218.

55. Roy, M.; Rochet, J.; Manzi, S.; Jargeat, P.; Gryta, H.; Moreau, P.-A.; Gardes, M. What determines Alnus-associated ectomycorrhizal community diversity and specificity? A comparison of host and habitat effects at a regional scale. New Phytol. 2013, 198, 1228-1238. [CrossRef] [PubMed]

56. Breitenbach, J.; Kranzlin, F. Fungi of Switzerland; Verlag Mykologia: Lucerne, Switzerland, 2000; Volumes 1-5, pp. 1-342.

57. Yurchenko, E.O. Natural substrata for corticioid fungi. Acta Mycol. 2006, 41, 113-124. [CrossRef]

58. Ainsworth, M. Some British alder-associated wood- inhabiting fungi. Field Mycol. 2010, 11, 10-15. [CrossRef]

59. Kotiranta, H.; Saarenoksa, R.; Kytövuori, I. Aphyllophoroid fungi of Finland. A check-list with ecology, distribution, and threat categories. Norrlinia 2009, 19, 1-223.

60. Niemelä, T.; Kotiranta, H. Polypore survey of Finland 3. The genera Coltricia, Inonotopsis, Inonotus and Onnia. Karstenia 1983, 23, 15-25. [CrossRef]

61. Küffer, N.; Senn-Irlet, B. Diversity and ecology of corticioid basidiomycetes in green alder stands in Switzerland. Nova Hedwig. 2000, 71, 131-143.

62. Piętka, J.; Grzywacz, A. Grzyby wielkoowocnikowe stwierdzone na olszy czarnej Alnus glutinosa (L.) Gaertn. w drzewostanach olszowych wykazujących objawy zamierania. Sylwan 2018, 162, 22-31.

63. Larsson, K.-H. Two new species in Hyphoderma. Nord. J. Bot. 1998, 18, 121-127. [CrossRef]

64. Volobuev, S.; Okun, M.; Ordynets, A.; Spirin, V. The Phanerochaete sordida group (Polyporales, Basidiomycota) in temperate Eurasia, with a note on Phanerochaete pallida. Mycol. Prog. 2015, 14, 1-13. [CrossRef]

65. Vellinga, E.C. Pluteaceae Kolt. \& P. In Flora Agaricina Neerlandica; Bas, C., Noordeloos, M.E., Kuyper, T.W., Vellinga, E.C., Eds.; A. A. Balkema: Rotterdam, The Netherlands, 1990; Volume 2, pp. 31-64.

66. Konstantinidis, G. 1000 Mushrooms of Western Makedonia; The Mushroom Friends Society of Western Makedonia: Kastoria, Greece, 2006; pp. 1-523. (In Greek)

67. Ortega, A.; Esteve-Raventós, F. A new species of Gymnopilus (Cortinariaceae) from sandy soils in Pinus forests. Persoonia 2005, 18, 505-510. 
68. Guzman-Davalos, L.; Ortega, A.; Contu, M.; Vizzini, A.; Rodriguez, A.; Villalobos-Arambula, A.R.; Santerre, A . Gymnopilus maritimus (Basidiomycota, Agaricales), a new species from coastal psammophilous plant communities of northern Sardinia, Italy, and notes on G. arenophilus. Mycol. Prog. 2009, 8, 195-205. [CrossRef]

69. Bas, C. Hydropus (Kühner) ex Singer. In Flora Agaricina Neerlandica; Bas, C., Kuyper, T.W., Noordeloos, M.E., Vellinga, E.C., Eds.; A. A. Balkema: Rotterdam, The Netherlands, 1999; Volume 4, pp. 166-172.

70. Ortega, A.; Zea, M. Hydropus floccipes var. luteipes Ortega \& Zea var. nov. en España meridional. Bol. Soc. Micol. Madr. 1991, 15, 189-191.

71. Vellinga, E.C. Lepiota (Pers.: Fr.) S.F. Gray. In Flora Agaricina Neerlandica; Noordeloos, M.E., Kuyper, T.W., Vellinga, E.C., Eds.; A. A. Balkema: Rotterdam, The Netherlands, 2001; Volume 5, pp. 109-151.

72. Gierczyk, B.; Kujawa, A.; Szczepkowski, A.; Chachuła, P. Rare species of Lepiota and related genera. Acta Mycol. 2011, 46, 137-178. [CrossRef]

73. Noordeloos, M.E.; Bas, C. Flora Agaricina Neerlandica; Bas, C., Kuyper, T.W., Noordeloos, M.E., Vellinga, E.C., Eds.; A. A. Balkema: Rotterdam, The Netherlands, 1995; Volume 3, pp. 67-75.

74. Deschuyteneer, D.; Melzer, A. Psathyrella hellebosensis, a new species from Belgium. Bull. AMFB 2017, 10, 3-10.

75. Voto, P.; Dovana, F.; Garbelotto, M. A revision of the genus Psathyrella, with a focus on subsection Spadiceogriseae. FUSE 2019, 4, 97-170. [CrossRef] [PubMed]

76. Noordeloos, M.E. Entoloma s.l. Supplemento. Fungi Europei Vol. 5a; Candusso: Alassio, Italy, 2004; pp. 1-760.

77. Glassman, S.; Levine, C.; DiRocco, A.; Battles, J.J.; Bruns, T.D. Ectomycorrhizal fungal spore bank recovery after a severe forest fire: Some like it hot. ISME J. 2016, 10, 1228-1239. [CrossRef] [PubMed]

78. Zotti, M.; Persiani, A.M.; Ambrosio, E.; Vizzini, A.; Venturella, G.; Donnini, D.; Angelini, P.; Di Piazza, S.; Pavarino, M.; Lunghini, D.; et al. Macrofungi as ecosystem resources: Conservation versus exploitation. Plant Biosyst. 2013, 147, 219-225. [CrossRef]

(C) 2020 by the authors. Licensee MDPI, Basel, Switzerland. This article is an open access article distributed under the terms and conditions of the Creative Commons Attribution (CC BY) license (http://creativecommons.org/licenses/by/4.0/). 